\title{
Hydrogen Peroxide and Redox Regulation of Developments
}

\author{
Christine Rampon ${ }^{1,2}{ }^{-}$, Michel Volovitch ${ }^{1,3}$, Alain Joliot ${ }^{1}$ and Sophie Vriz ${ }^{1,2, *(1)}$ \\ 1 Center for Interdisciplinary Research in Biology (CIRB), College de France, CNRS, INSERM, PSL Research \\ University, 75231 Paris, France; Christine.rampon@college-de-france.fr (C.R.); \\ Michel.volovitch@ens.fr (M.V.); alain.joliot@college-de-france.fr (A.J.) \\ 2 Sorbonne Paris Cité, Univ Paris Diderot, Biology Department, 75205 Paris CEDEX 13, France \\ 3 École Normale Supérieure, Department of Biology, PSL Research University, 75005 Paris, France \\ * Correspondence: vriz@univ-paris-diderot.fr
}

Received: 19 September 2018; Accepted: 10 October 2018; Published: 6 November 2018

check for updates

\begin{abstract}
Reactive oxygen species (ROS), which were originally classified as exclusively deleterious compounds, have gained increasing interest in the recent years given their action as bona fide signalling molecules. The main target of ROS action is the reversible oxidation of cysteines, leading to the formation of disulfide bonds, which modulate protein conformation and activity. ROS, endowed with signalling properties, are mainly produced by NADPH oxidases (NOXs) at the plasma membrane, but their action also involves a complex machinery of multiple redox-sensitive protein families that differ in their subcellular localization and their activity. Given that the levels and distribution of ROS are highly dynamic, in part due to their limited stability, the development of various fluorescent ROS sensors, some of which are quantitative (ratiometric), represents a clear breakthrough in the field and have been adapted to both ex vivo and in vivo applications. The physiological implication of ROS signalling will be presented mainly in the frame of morphogenetic processes, embryogenesis, regeneration, and stem cell differentiation. Gain and loss of function, as well as pharmacological strategies, have demonstrated the wide but specific requirement of ROS signalling at multiple stages of these processes and its intricate relationship with other well-known signalling pathways.
\end{abstract}

Keywords: $\mathrm{H}_{2} \mathrm{O}_{2}$; redox signalling; development; regeneration; adult stem cells; metazoan

\section{Introduction}

For a long time, reactive oxygen species (ROS), including hydrogen peroxide $\left(\mathrm{H}_{2} \mathrm{O}_{2}\right)$, were considered deleterious molecules. Emphasis was given to their role in neutrophils where they are produced to contribute to anti-microbial defence [1], and extensive studies have been performed on ROS over-production due to mitochondrial dysfunction in neurological disorders or cancer progression [2-4]. Consistent with these detrimental functions, attention has been almost exclusively focused on their toxicity, and many studies strengthened this aspect of redox biology. However, pioneer works highlighted a new role of ROS in signalling, which led to the emergence of the redox signalling field [5,6]; recent reviews in $[7,8]$. Redox signalling soon also proved to be important during animal development for review [9,10]. In 2017, Helmut Sies, a pioneer in redox biology, reviewed the topic and developed the concept of oxidative eustress (physiological redox signalling) and oxidative distress (pathophysiological disrupted redox signalling), bringing the two faces of ROS back together [11]. As recently noted [12], a new reading of the past literature might shed a new light on the tenets of redox signalling. Relevant issues are the nature of the ROS invoked, the accurate localization of its site of production, and its concentration, spreading and dynamics in the context of a 
defined physiological process. The present review focuses on $\mathrm{H}_{2} \mathrm{O}_{2}$, a central ROS in redox signalling during development and regeneration in metazoans, and its interplay with the redox machinery. We will not address the role of other reactive species, and readers are referred to excellent reviews on Reactive Nitrogen Species (RNS) or oxidized lipids recently published [13,14].

$\mathrm{H}_{2} \mathrm{O}_{2}$ is the major ROS produced by cells that acts in signalling pathways as a second messenger [11,15-17]. $\mathrm{H}_{2} \mathrm{O}_{2}$ is a by-product of many oxidative reactions, such as oxidative protein folding in the endoplasmic reticulum (ER) and peroxisomal enzyme activities. For signalling purposes, the main sources of $\mathrm{H}_{2} \mathrm{O}_{2}$ are the mitochondrial respiratory chain and NADPH oxidases (NOXs) [18]. NOXs are trans-membrane proteins that use cytosolic NADPH as an electron donor. NOXs belong to multi-component complexes that generate either $\mathrm{O}_{2}{ }^{-}$(NOX 1, 2, 3 and 5) or $\mathrm{H}_{2} \mathrm{O}_{2}$ (NOX 4, DUOX 1 and 2) upon appropriate stimulation (by growth factors, cytokines ... ) $[19,20]$. Even when the primary product of NOX activity is $\mathrm{O}_{2}{ }^{-}$, it is largely and immediately transformed into $\mathrm{H}_{2} \mathrm{O}_{2}$ by a superoxide dismutase (SOD) enzyme physically associated with NOX, or it dismutates spontaneously at low $\mathrm{pH}$ levels. Several NOXs are located at the plasma membrane, which is a hub for cell signalling. In this case, $\mathrm{H}_{2} \mathrm{O}_{2}$ is delivered in the extracellular space, a somehow puzzling situation considering that most known $\mathrm{H}_{2} \mathrm{O}_{2}$ targets localize in the cell interior. It was first thought that $\mathrm{H}_{2} \mathrm{O}_{2}$ could pass from the extracellular to the intracellular milieu by passive diffusion through the plasma membrane, but it was later shown that $\mathrm{H}_{2} \mathrm{O}_{2}$ has poor lipid membrane diffusion capacities and crosses into cells via aquaporin channels [21-23]. This facilitated transport of $\mathrm{H}_{2} \mathrm{O}_{2}$ across the plasma membrane is itself subject to redox regulation [24], and further investigations are needed to better understand the role of aquaporins in redox signalling. The unique and specific enzyme for $\mathrm{H}_{2} \mathrm{O}_{2}$ degradation into $\mathrm{H}_{2} \mathrm{O}$ is the ubiquitously expressed protein catalase. It mainly localizes in the peroxisome where it is devoted to the reduction of excess $\mathrm{H}_{2} \mathrm{O}_{2}$ produced there. However, it can also be secreted by an unknown mechanism and associate with the plasma membrane [25-27] or spread in the extracellular milieu [28].

The main physiological target of $\mathrm{H}_{2} \mathrm{O}_{2}$ action is the reversible oxidation of cysteine residues in proteins. Modification only occurs on the thiolate anion form $\left(\mathrm{S}^{-}\right)$. However, at physiological $\mathrm{pH}$, most cysteines are protonated and thus react weakly with $\mathrm{H}_{2} \mathrm{O}_{2}$. However, the $\mathrm{pK}_{\mathrm{a}}$ of cysteine greatly depends on its protein environment and can reach several units below $\sim 8.5$, the approximate value of cysteine alone [29], making these residues ionized and reactive. $\mathrm{H}_{2} \mathrm{O}_{2}$ oxidizes the thiolate anion to produce sulfenic acid, which is highly reactive and readily forms a disulfide bond in contact with accessible -SH group. Reciprocally, in reducing conditions, disulfide bonds can be easily cleaved to restore the thiol functions. As oxidative condition increases, sulfenic acid will further oxidize to sulfinic and ultimately sulfonic derivatives. These two reactions are generally irreversible deleterious modifications; however, exceptions were reported for sulfinic derivatives (see below). Redox signalling depends both on the local concentration of $\mathrm{H}_{2} \mathrm{O}_{2}$ and the state (protonated or deprotonated) of the cysteine. Although some cysteines can be directly oxidized by $\mathrm{H}_{2} \mathrm{O}_{2}$, most of them require prior activation to be deprotonated, involving additional redox-sensitive relays. The best candidates for this relay function appear to be proteins first identified as antioxidant safe-guarders [30-36] reviews in [37-41], and they will be discussed below. It is now clear that the role of $\mathrm{H}_{2} \mathrm{O}_{2}$ signalling in oxidative eustress has to integrate the entire redox machine.

\section{The Redox Machine}

The central redox machine contains at least six main protein families: thioredoxin reductases (TrxRs), thioredoxins (Trxs), peroxiredoxins (Prxs), glutathione reductases (GRs), glutaredoxins (Grxs) and glutathione peroxidases (Gpxs) (Figure 1) [for general reviews, see [42-45]. Moreover, as schematized in Figure 1, the activities of all enzymes in the redox machine are interconnected (some additional branches between cycles have been omitted), and the final outcome of thiol-oxidation reactions depends on many parameters, making computational modelling useful but hampering genetic approaches. 


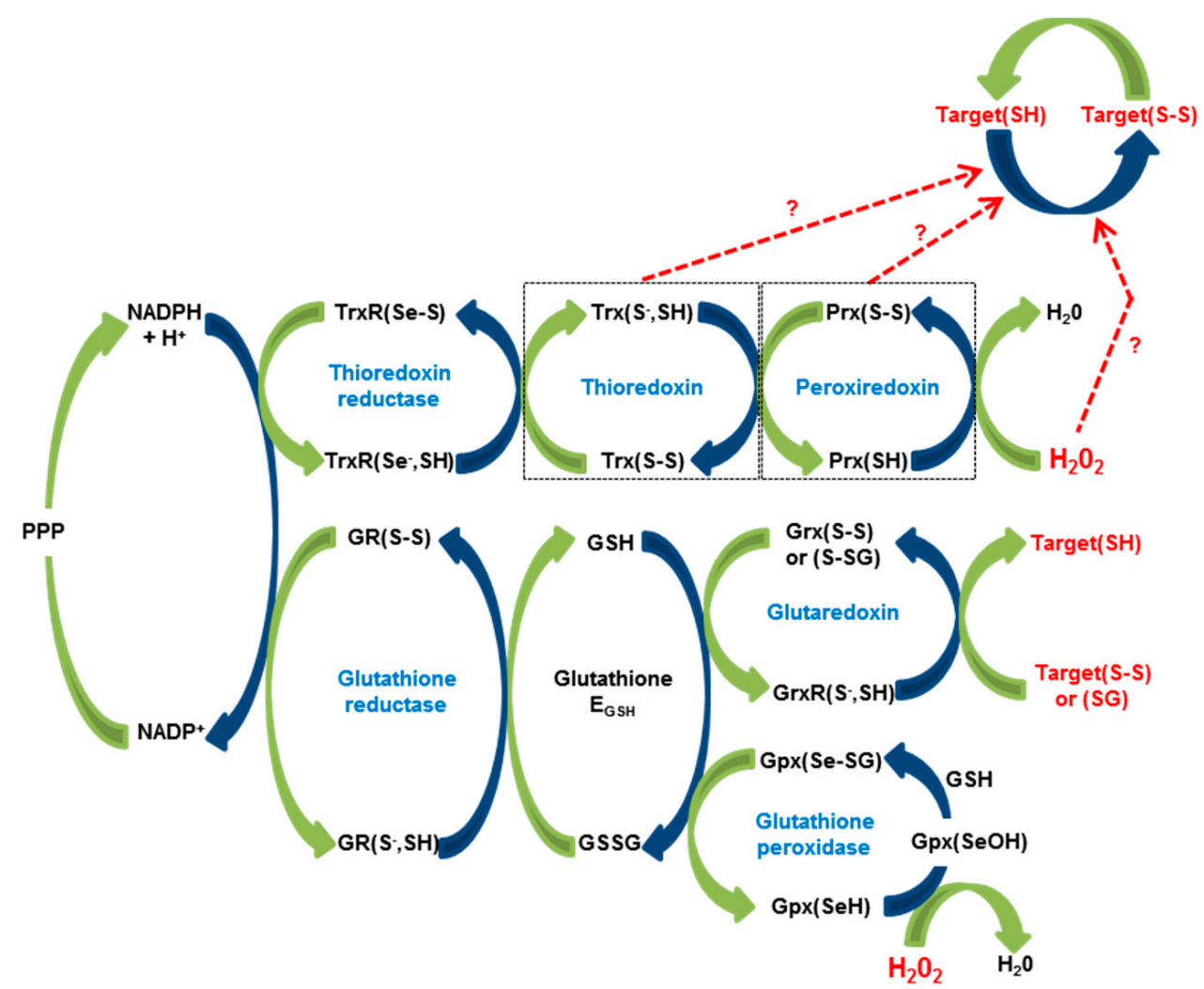

Figure 1. The redox machinery. Interconnection of redox couples from $\mathrm{H}_{2} \mathrm{O}_{2}$ to thiol targets are represented. $\mathrm{H}_{2} \mathrm{O}_{2}$ is a by-product of oxidative reactions. Major sources include mitochondrial respiratory chain and NOXs for review [18]. PPP: Pentose Phosphate Pathway.

As mentioned in the introduction, the central redox machine has pleiotropic functions. In addition to detoxification of harmful amounts of ROS, they also act as sensors of oxidant concentrations and can even acquire new functions, such as chaperones activity for some Prxs [46] for a review. This sensor and/or transducer functions are very important given that the vast majority of redox-sensitive proteins are poorly sensitive to direct oxidation by $\mathrm{H}_{2} \mathrm{O}_{2}$ (a possible exception, PTP1B, is discussed in [39]). Prxs have attracted considerable attention as potent mediators redox signals, as first established in yeast [31,47-50], and some years after in mammals. Ledgerwood and colleagues demonstrated that Prx1 participates in the propagation of peroxide signals via disulfide exchange with the target kinase ASK1 [51], and the group of Tobias Dick showed that Prx2 forms a redox relay for $\mathrm{H}_{2} \mathrm{O}_{2}$ signalling together with the transcription factor STAT3 [36]. Very recently, the same group demonstrated that the relay activity of cytosolic Prxs (1 and 2) is not dependent on Trx1 or TrxR1 but is based on transient disulfide conjugates with protein targets and occurs mainly in conditions of fast response to small variations in $\mathrm{H}_{2} \mathrm{O}_{2}$ [52].

\section{Seeing Is Believing}

A critical step to model redox signalling is to determine the spatiotemporal localization and amount of the different protagonists. Several synthetic dyes were actively used to measure ROS and RNS [53-55]. However, these dyes are often poorly specific, do not penetrate in tissue, or are unstable. Moreover, their reaction with ROS/RNS is irreversible. In the last decade, a major effort was devoted to develop genetically encoded fluorescent biosensors for the redox machine elements.

\section{1. $\mathrm{H}_{2} \mathrm{O}_{2}$ Sensors}

For all ROS, ex vivo and in vivo measurements of $\mathrm{H}_{2} \mathrm{O}_{2}$ concentration are challenging due to its short half-life, fast-spreading and high reactivity. The development of a genetically encoded 
fluorescent biosensor specific for $\mathrm{H}_{2} \mathrm{O}_{2}$ revolutionized the field. It provides access to the dynamics of $\mathrm{H}_{2} \mathrm{O}_{2}$ concentration in living systems and its modulation by genetic or chemical approaches. This goal was first achieved by Vsevolod Belousov who designed the HyPer probe [56]. The HyPer biosensor is based on the fusion of a circularly permutated fluorescent protein (cpYFP) with the $\mathrm{H}_{2} \mathrm{O}_{2}$-sensing domain of E. coli OxyR. Two cysteines of OxyR moiety form a disulfide bond in the presence of $\mathrm{H}_{2} \mathrm{O}_{2}$ and the resulting conformational change induces a modification of cpYFP spectra, which allows a ratiometric measurement of $\mathrm{H}_{2} \mathrm{O}_{2}$ levels. Advantages of this probe are its high sensitivity (nanomolar), its reversibility and its fast reaction rate constant. Moreover, ratiometric measurement is independent of the expression level. The main drawback of this sensor is its sensitivity to $\mathrm{pH}$. To circumvent this problem, a cysteine-mutated form of HyPer (SypHer), which is still sensitive to $\mathrm{pH}$ but no longer to $\mathrm{H}_{2} \mathrm{O}_{2}$, can be used as a control or to measure $\mathrm{pH}$ in vivo [57]. Since the initial version, HyPer probe has evolved, and the HyPer family currently includes members with different spectral and redox properties [58].

When expressed in Xenopus laevis oocytes, HyPer revealed an oscillating production of $\mathrm{H}_{2} \mathrm{O}_{2}$ induced by fertilization. This production of $\mathrm{H}_{2} \mathrm{O}_{2}$ is of mitochondrial origin, dependent on calcium waves initiated by fertilization and involved in cell cycle progression at the beginning of development [59]. HyPer was also expressed by transgenesis in two animal models (nematode and fish), where it revealed a highly dynamic fluctuation in $\mathrm{H}_{2} \mathrm{O}_{2}$ levels during embryonic and post-embryonic development. In Caenorhabditis elegans (where HyPer expression was under the control of the ubiquitous RPL-21 promoter), $\mathrm{H}_{2} \mathrm{O}_{2}$ levels were high during larval development (in the head, notably in the pharynx and neurons), strongly decreased at the transition to the adult stage, and remained low during most of the reproductive period [60]. A similar pattern was observed in Danio rerio transgenic animals with high levels of $\mathrm{H}_{2} \mathrm{O}_{2}$ during development and a massive reduction at 3 days post fertilization (dpf) when most of the developmental programmes have ended. Notably, in fish and nematode, HyPer revealed a highly dynamic pattern of $\mathrm{H}_{2} \mathrm{O}_{2}$ levels in the developing nervous system [61] (Figure 2).

Another type of $\mathrm{H}_{2} \mathrm{O}_{2}$ sensor was developed from a fusion between roGFP2 (a redox-sensitive GFP) and Orp1, the yeast $\mathrm{H}_{2} \mathrm{O}_{2}$ sensor and modulator of redox-sensitive transcription factor Yap1 [34]. Orp1 is sensitive to $\mathrm{H}_{2} \mathrm{O}_{2}$; once oxidized, Orp1 promotes the nearby oxidation of roGFP2 (as it does for Yap1), resulting in a shift of roGFP2 spectral properties. Compared with HyPer, this biosensor is insensitive to $\mathrm{pH}$ but less sensitive to $\mathrm{H}_{2} \mathrm{O}_{2}$. This lower affinity for $\mathrm{H}_{2} \mathrm{O}_{2}$ was overcome by fusion of roGFP2 to the yeast Prx Tsa2 (Tsa2 $\Delta C_{R}$ ) [63]. roGFP2-Orp1 has been successfully used to measure $\mathrm{H}_{2} \mathrm{O}_{2}$ in developing and adult Drosophila [64]. One of the advantages of genetically encoded sensors is their ability to be addressed to a cell-specific compartment upon fusion with appropriate targeting sequences. Differential targeting into either the cytosol or the mitochondria allowed Albrecht et al. to demonstrate the heterogeneity of $\mathrm{H}_{2} \mathrm{O}_{2}$ levels depending on the tissue and that $\mathrm{H}_{2} \mathrm{O}_{2}$ level is not coupled with the redox state of glutathione during development [64]. Cytosol/mitochondria expression of roGFP2-Orp1 in the germline of Caenorhabditis elegans revealed an increase in $\mathrm{H}_{2} \mathrm{O}_{2}$ levels in the proximal side of the germline and a peak within the oocytes and in the zygote [65]. An elegant approach preserving the redox status of roGFP2-Orp1 during tissue cryo-section allowed $\mathrm{H}_{2} \mathrm{O}_{2}$ measurements in mammalian development and adult tissues [66]. This strategy is very promising to acquire redox maps of non-optically accessible tissue. roGFP2-Orp1 was also targeted to zebrafish cardiomyocytes in different compartments (nucleus, mitochondria and cytosol) to follow $\mathrm{H}_{2} \mathrm{O}_{2}$ level variations during cardiac function and upon pharmaceutical treatments, demonstrating the interest of this $\mathrm{H}_{2} \mathrm{O}_{2}$ probe to score oxidant or antioxidant molecules [67]. 


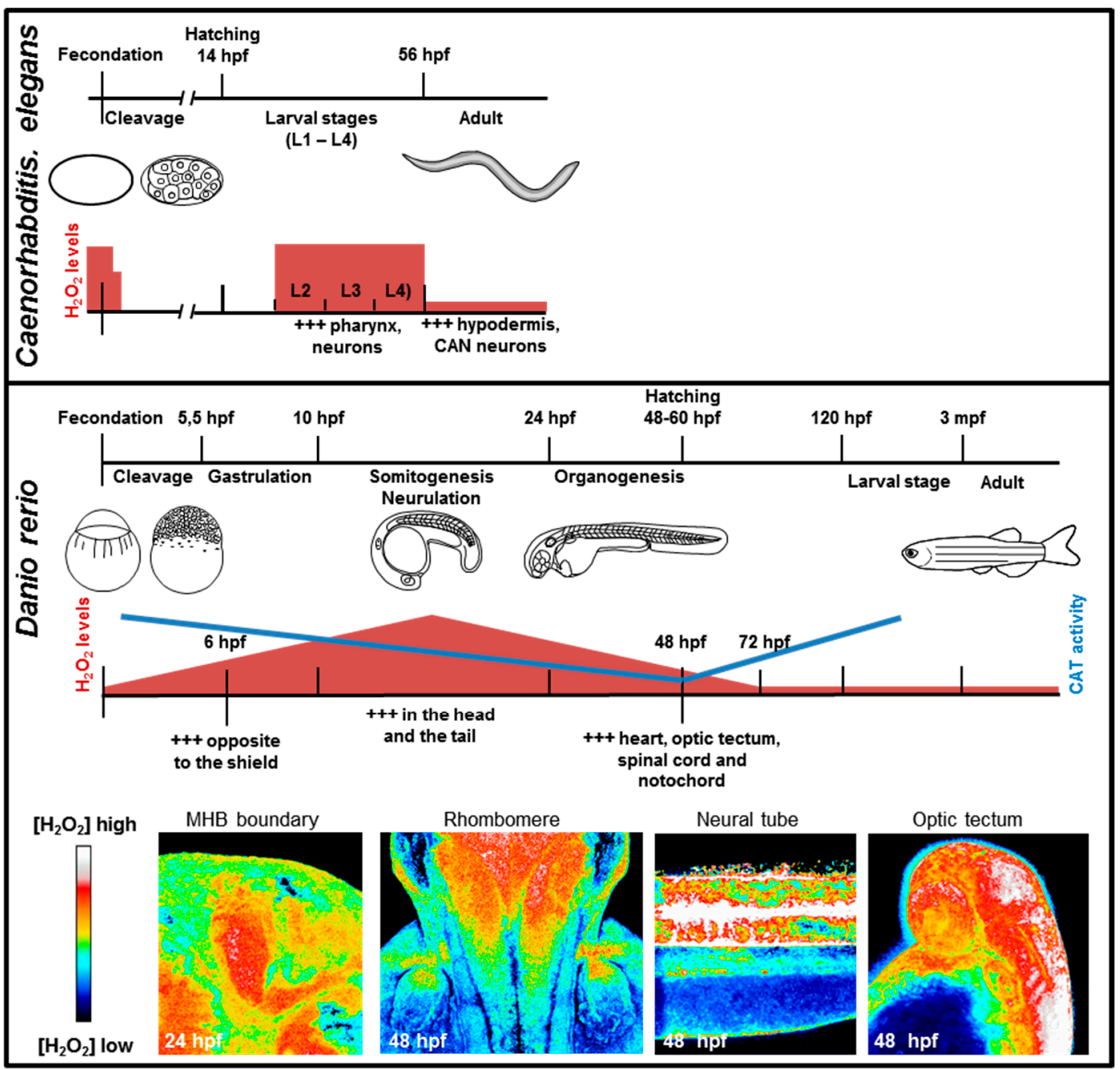

Figure 2. $\mathrm{H}_{2} \mathrm{O}_{2}$ detection during development. Upper panel: $\mathrm{H}_{2} \mathrm{O}_{2}$ detection during $C$. elegans development. Adapted from [62] and [60]. Middle panel: $\mathrm{H}_{2} \mathrm{O}_{2}$ levels and catalase activity during Danio rerio development. Adapted from [61]. Lower panel: HyPer fish reveal spatio-temporal dynamic and gradients of $\mathrm{H}_{2} \mathrm{O}_{2}$ during neural development. hpf: hours post fertilization, mpf: month post fertilization.

\subsection{Glutathione Redox Potential Sensors}

Glutathione plays a key role in cellular thiol-disulfide exchange reactions, and the GSH/GSSG ratio is considered a good indicator of redox balance ( $\mathrm{E}_{\mathrm{GSH}}$ ) (Figure 1). A fluorescent sensor for $\mathrm{E}_{\mathrm{GSH}}$ was generated by fusion of the roGFP2 with the human glutaredoxin-1 (Grx1). roGFP2 alone exhibits a slow response to redox changes. Grx1 fusion to roGFP2 resulted in a rapid equilibrium between the GSH/GSSG couple and the reporting redox couple (roGFP2red and roGFP2ox), thus reflecting the level of $\mathrm{E}_{\mathrm{GSH}}$ [68]. This sensor was introduced in several species. In Drosophila, it was addressed to mitochondria and cytosol to compare $\mathrm{E}_{\mathrm{GSH}}$ with $\mathrm{H}_{2} \mathrm{O}_{2}$ levels in developing structures and adults [64]. Live imaging of the third-instar larvae revealed high variations in mitochondrial $\mathrm{E}_{\mathrm{GSH}}$ amongst different tissues, whereas the cytosolic $\mathrm{E}_{\mathrm{GSH}}$ was almost constant [64]. Transgenic C. elegans expressing a cytosolic form of Grx1-roGFP2 under a ubiquitous promoter was used to analyse $\mathrm{E}_{\mathrm{GSH}}$ during development [62]. $\mathrm{E}_{\mathrm{GSH}}$ decreases globally during development and then remains constant in adult except in the spermathecae where fertilization occurs [62]. 


\subsection{NADPH Sensor: iNap}

NADPH is a key element in the redox machine as a final electron donor for thiol oxidation by $\mathrm{H}_{2} \mathrm{O}_{2}$. A genetically encoded fluorescent indicator for NADPH (iNap sensor) was developed by mutagenesis of the ligand binding site of the NADH/NAD+ sensor SoNar to switch the selectivity from NADH to NADPH [69]. iNap can be used in vivo, and a proof of concept experiment was performed in a wound healing assay in zebrafish larvae. In combination with a red version of HyPer, the iNap biosensor revealed the concomitant decrease of NADPH levels after tissue wounding with an increase in $\mathrm{H}_{2} \mathrm{O}_{2}$ levels, which is consistent with NADPH consumption by NOXs during wound healing [69].

All these sensors provide invaluable information on cellular redox status in vivo. However, it is worth reminding that all $\mathrm{H}_{2} \mathrm{O}_{2}$ sensors consume $\mathrm{H}_{2} \mathrm{O}_{2}$ to measure its concentration. Thus, there is room to improve these systems in particular through increased sensitivity. Only one molecule of $\mathrm{H}_{2} \mathrm{O}_{2}$ is consumed to modify each molecule of sensor for both HyPer and roGFP2-Orp1. However, for the later, it also depends on the local redox potential. This is a clear illustration of a common difficulty: seeing is modifying.

\section{Redox Signalling in Animal Development and Regeneration}

$\mathrm{H}_{2} \mathrm{O}_{2}$ is generated in response to many stimuli, including cytokine or growth factors, which are involved in embryonic development and adult homeostasis. Given redundancy in the redox machinery components, most single Knock out (KOs) in mice are viable, and embryonic development generally occurs normally [70]. Metazoan development can be divided into 3 phases: (1) fertilization and cleavage period, (2) gastrulation, and (3) morphogenesis. At the adult stage, most tissues are continuously renewed and, in some species, rebuilt after amputation. This section will describe the state of the art for the role of redox signalling during these processes. Many molecular targets of redox signalling are now known, as well as the mechanisms by which their redox balance influences the pathways they belong to, for which excellent recent reviews exist [7-10,71]. The role of RNS and oxidative stress in pathologies of the nervous system, which are not discussed here, are extensively reviewed in [72-74]. Finally, it is worth mentioning that some developmental effects of redox signalling in the brain only become apparent much later (as for instance in the case of critical periods [75], mental illnesses, such as schizophrenia [76], or autism-like behaviours in mouse [77]). These effects have only been analysed in the context of their dysregulation, but their normal progress certainly warrants better examination.

\subsection{Embryonic Development}

\subsubsection{NADPH Oxidase Complexes in Embryonic Development}

Given the importance of NOXs in anti-microbial defence, inflammation, disorders including cancers, and more generally in the maintenance of redox balance, most studies on these enzymes in metazoans focus on adult expression. Some NOXs exhibit broad distribution among tissues (Nox2 was first believed to be exclusively expressed in neutrophils and macrophages and is currently known to present the largest distribution). Others are more restricted (Nox3 is predominantly expressed in the inner ear), but none of them is ubiquitously expressed. Constitutive expression coexists with induction phenomena (for review see $[19,78]$. NOX expression also greatly varies during development (Table 1). The most detailed study was performed by qPCR and in situ hybridization in developing zebrafish [79]. Unlike the uniform and homogeneous expression of Nox2, Nox1 and Nox5 expression is high during gastrulation and then decreases to a basal level upon morphogenesis. During this period of development, Nox1 expression is increased in the brain. The expression of dual oxidase (Duox), which is a member of the NOX family, is increased during late morphogenesis [79]. In rodents, Duox expression patterns were described in embryonic thyroid [80] and Nox2 and 4 were looked at during limb formation [81]. Though useful, these expression data did not provide a clear picture of the 
physiological function of these enzymes. Till the advent of tools enabling to study redox biology in live organisms (see below), the contribution of $\mathrm{H}_{2} \mathrm{O}_{2}$ signalling to developmental processes was essentially analysed in embryonic stem (ES) cells. More than 10 years ago, it was proven that ES cell differentiation into cardiac lineage was dependent on NOX enzymes [82,83]. More examples of ES cell sensitivity to redox potential are now known, which can be found in recent reviews on the subject $[84,85]$.

Table 1. Expression of the redox machinery genes during Danio rerio development.

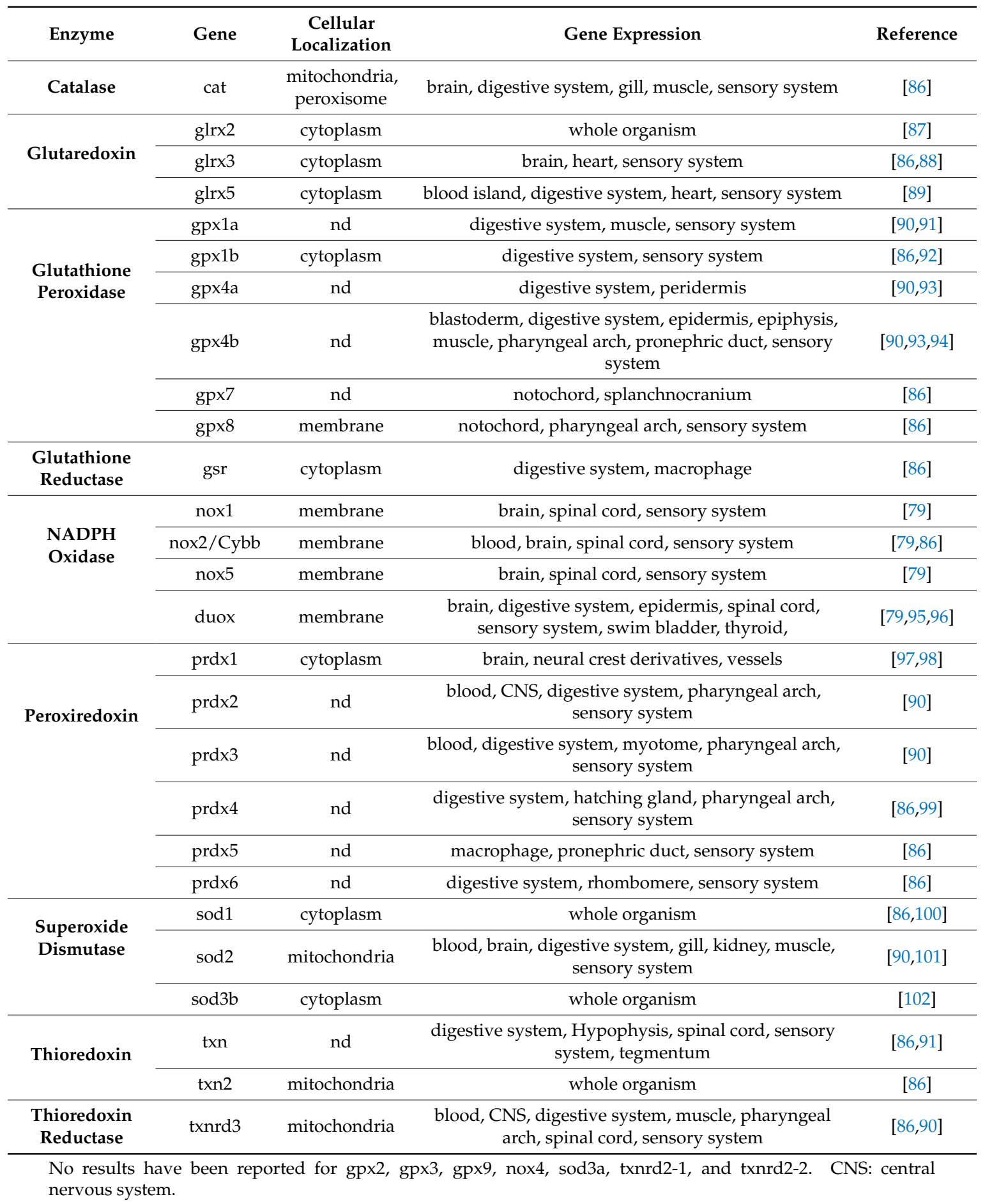

The use of the HyPer probe in a live animal revealed a surprisingly high level of oxidation during zebrafish development, and $\mathrm{H}_{2} \mathrm{O}_{2}$ levels proved to be heterogeneous and dynamic in space 
and time [61] (Figure 2). $\mathrm{H}_{2} \mathrm{O}_{2}$ levels occasionally exhibit a graded distribution with clear functional outcome. This distribution occurs in the embryonic tectum where the organization of the retinotectal projections is impaired by Pan NOX inhibition [61]. Nox2 invalidation using the CRISPR/Cas9 strategy induced the same phenotype [103], confirming Nox2 involvement in axon pathfinding during zebrafish development. Very recently, the group of E. Amaya proved that Duox activity was necessary for the development of zebrafish thyroid [104], and that ROS play a role in Xenopus mesoderm formation [59]. A role for Nox enzymes was also evidenced ex vivo for the differentiation of chondrocytes [81] or endometrial cells [105], the establishment of rat hippocampal neuron polarity in culture [106,107], the in vitro maturation of rat cerebellar granule neurons [108], and growth cone dynamics in Aplysia neuron [109-111]. Nox were also shown to be involved in epithelial-to-mesenchymal transition in normal or tumoral epithelial cell lines [112,113].

\subsubsection{Catalase, Superoxide Dismutases and Glutathione Systems in Embryonic Development}

Catalase, Sod1 and GPx expression and activities have been analysed during mice development from 8 days of gestation to adulthood [114]. mRNAs of these 3 proteins increase during somitogenesis. Then, catalase activity increases after birth, whereas Sod1 and GPx activities reach a plateau. In zebrafish, SOD activity is globally constant throughout morphogenesis until $7 \mathrm{dpf}$, whereas an increase in catalase activity is observed from $48 \mathrm{hpf}$ onward when morphogenesis is almost completed [61], (Figure 2). In Drosophila, catalase protein is minimally detectable during embryogenesis and enhanced during the third instar larval stage and after the first day of pupal development [115]. It thus appears that low levels of catalase expression during development and high levels in mature tissues represent a general property that has been verified in mice, Drosophila and zebrafish.

GSH/GSSG balance is a crucial redox parameter during development [for review: [116]. Embryos from mutant mice invalidated for the enzymes responsible for GSH synthesis fail to gastrulate, do not form mesoderm, develop distal apoptosis, and die before day 8.5 [117,118]. In zebrafish, the total amount of glutathione doubles during embryonic development. The redox potential ( $\mathrm{E}_{\mathrm{GSH}}$ ) is high in eggs and late larval stage but very low during morphogenesis [119]. This study defined 4 GSH contexts during embryonic development: (1) high $\mathrm{E}_{\mathrm{GSH}}$ and low GSH in mature oocytes, (2) low $\mathrm{E}_{\mathrm{GSH}}$ and low GSH from mid-blastula to $24 \mathrm{hpf}$, (3) high $\mathrm{E}_{\mathrm{GSH}}$ and high GSH during organogenesis (30-48 hpf) and (4) high $\mathrm{E}_{\mathrm{GSH}}$ and high GSH in mature larvae.

Grx patterns of expression during development have not been systematically investigated, but expression of Grx2 and its isoforms in vertebrate tissues at various stages (mostly adults) is described in [120-123]. Their role during development has been demonstrated in different models. One of the first hint (though outside metazoan) was that Grx1 affects cell fate decision in the culmination process in Dictyostelium discoideum [124]. It was subsequently shown that knocking down (KD) cytosolic Grx2 in zebrafish embryo impaired the development of the central nervous system. Grx2 is indeed essential for neuronal differentiation, survival and axon growth [87]. In mammals, Grx2 controls axon growth via a dithiol-disulfide switch affecting the conformation of CRMP2, a mediator of semaphorin-plexin signalling pathway [125]. The same Grx2 isoform is also required for correct wiring of embryonic vasculature in zebrafish by de-glutathionylation of the active site of the NAD-dependent deacetylase Sirtuin-1 [126]. Grx2 is also implicated in embryonic heart formation. Grx2 KD in zebrafish embryo prevented neural crest cell migration into the primary heart field, impairing heart looping [127]. The role of other members of the Grx family was also described in erythropoiesis. Grx5 is essential to zebrafish haeme synthesis through assembly of the Fe-S cluster, and this role is apparently conserved in humans [89]. Grx3 is also crucial to red blood cell formation in zebrafish as demonstrated by the reduced number of erythrocytes in embryos treated with Grx3 morpholinos and is required in human cells for the biogenesis of Fe-S proteins, as demonstrated by silencing Grx3 expression in HeLa cells [88]. Grx3 KO in mice induces a delay in development and eventually death approximately 12.5 days of gestation. Ex vivo analysis of Grx3 ${ }^{-/-}$cells reveals impaired growth and cell cycle progression at the G2/M transition [128]. The loss of Grx3 also disturbs 
the development of mammary alveoli during pregnancy and lactation [129]. In addition to these roles during development proper, Grx proteins are also involved in various physio-pathological processes (for review [130]).

\subsubsection{Thioredoxin System in Embryonic Development}

Two distinct thioredoxin/thioredoxin reductase systems, $\operatorname{Tr} x 1$ and $\operatorname{Tr} x 2$, are present in mammalian cells in the cytosol and mitochondria. Trx 1 and Trx 2 are ubiquitously expressed, but Trx 2 is expressed at higher levels in metabolically active tissues, such as heart, brain, and liver [131]. Interestingly, in mice, Trx1 (the cytosolic and nuclear Trx) KO is embryonic lethal early after implantation [132] and presents a dramatically reduced proliferation of inner mass cells. Trx2 (the mitochondrial form) $\mathrm{KO}$ is also embryonic lethal. Embryos die later during development (between 10.5 and $12.5 \mathrm{dpf}$ ), and lethality is associated with increased in apoptosis and exencephaly development [133]. Trx2 KD in zebrafish increases apoptosis and induces developmental defects in the liver [134]. In chick, Trx2 KD impairs post-mitotic neurons and induces massive cell death [135]. Thioredoxin reductases (TrxRs) KO reveals that TrxR1 (non-mitochondrial form) is embryonic lethal (E10.5) with multiple abnormalities in all organs except heart [136], whereas TrxR2 KO leads specifically to haematopoietic and heart defects [137]. These works demonstrate a clear dichotomy in the tissue specificity of TrxR 1 and 2 actions during development: broad or restricted to heart and haematopoietic lineage development. In addition, Trxs play critical roles in immune response, cancer (for review [138]), and various pathologies in the nervous system (for reviews [72,74]).

\subsubsection{Peroxiredoxin Systems in Embryonic Development}

The peroxiredoxins (Prxs) family includes 6 members in vertebrates. These enzymes have been mostly studied in physio-pathological contexts or ex vivo where it was demonstrated that Prxs are major regulators of cell adhesion and migration [139]. In vivo, Prxs regulate cadherin expression during early Drosophila development [140]. Prxs are typically broadly expressed in embryos with mild specificity amongst isoforms. However, an exhaustive analysis in Xenopus laevis reveals maternal expression of prx1, 2, 3 and 6, which persists through all developmental stages. In contrast, Prx 4 mRNA becomes detectable at gastrulation and increases afterwards, and Prx 5 mRNA is always detected but at low levels. Additional specificities are revealed by in situ hybridization. Specifically, Prx 1 is expressed in anterior structures, and Prx4, 5 and 6 expression is preferentially detected in somites [141]. This pattern of expression is not completely conserved between Xenopus and other vertebrates. In zebrafish, Prdx1 is expressed in developing vessels, and Prdx1 KD induces vascular defects [97]. In mice, proteomic analysis suggested that prx1 is involved in digit formation where it regulates interdigit apoptosis [142]. One of the best examples of Prxs' roles during normal differentiation is the involvement of Prx 1 and Prx 4 in the formation of motor neurons in the spinal cord of chicken and mouse [143,144].

Sexual reproduction and more precisely gamete formation is an unusual process regarding redox signalling. NOXs are involved in spermatogonia and germline stem cell renewal [145]. Moreover, a significant amount of $\mathrm{H}_{2} \mathrm{O}_{2}$ is needed to favour disulfide bridge formation during spermatozoa maturation and capacitation (for review [146]). Conversely, ROS insult should be neutralized to protect DNA and maintain genomic integrity from generation to generation. Several Gpx members are involved in these opposite aspects of redox signalling [147].

\subsection{Adult Stem Cells and Tissue Homeostasis}

During life, adult stem cells replenish damaged and lost tissues. In recent years, $\mathrm{H}_{2} \mathrm{O}_{2}$ appeared to be a major component of stem cell niche, stem cell renewal and recruitment for differentiation (for review [148,149]). In some studies, an increase in $\mathrm{H}_{2} \mathrm{O}_{2}$ is responsible for stem cell differentiation. In Drosophila, increased $\mathrm{H}_{2} \mathrm{O}_{2}$ induces the differentiation of haematopoietic progenitor cells, whereas a reduction delays the expression of differentiation markers [150]. In mammals, an increase in $\mathrm{H}_{2} \mathrm{O}_{2}$ 
induces vascular muscle cell [151] or blood stem cell [152] differentiation. In an apparent contradiction, high $\mathrm{H}_{2} \mathrm{O}_{2}$ levels are associated with stem cell renewal and proliferation. The renewal of intestinal stem cells in Drosophila is dependent on $\mathrm{H}_{2} \mathrm{O}_{2}$ [153], and self-renewal of neural stem cells is under the control of NOX activity in the mouse [154,155]. These opposite effects of $\mathrm{H}_{2} \mathrm{O}_{2}$ illustrate our limited understanding of cell fate regulation by redox signalling but both strengthen the relevance of ROS levels in the control of stem cell behaviour and the need for their tight regulation. Some clues come from the induced pluripotent stem cell (iPSC) field where $\mathrm{H}_{2} \mathrm{O}_{2}$ increase is essential during the early phase of iPSC generation. Reduction of $\mathrm{H}_{2} \mathrm{O}_{2}$ levels by NOX KD or antioxidant treatment suppresses nuclear reprogramming [156]. NOX2 is also involved in iPSc differentiation into endothelial cells [157].

\subsection{Regeneration}

Some species have the ability to regenerate damaged or removed body parts at adulthood [158-160]. Regeneration is probably the best paradigm of adult morphogenesis. The first step of regeneration is wound repair and the formation of a wound epidermis. Shortly after wound epidermis formation, progenitor cells are generated via stem cells that are recruited and the dedifferentiation of differentiated cells [159,161,162]. The newly formed progenitors (and stem cells in some systems) migrate to the wound epithelium to form a mass of undifferentiated cells called the blastema. The entire missing structure will be formed by differentiation and morphogenesis of blastema cells. The process of regeneration can be divided into 3 modules: (1) injury immediate response (wound healing), (2) regeneration induction (blastema formation), (3) formation of the missing structure (blastema growth, differentiation and patterning) [163] (Figure 3A).

It has been known for a long time that wounds generate ROS, specifically $\mathrm{H}_{2} \mathrm{O}_{2}$, in phylogenetically diverse organisms, such as Drosophila melanogaster, C. elegans, Danio rerio, [171-174], and plants [175-177]. In zebrafish, $\mathrm{H}_{2} \mathrm{O}_{2}$ production triggered by wounding is restricted to the first two hours following injury in larva [172] and adult [166]. After a lesion is generated, a gradient of $\mathrm{H}_{2} \mathrm{O}_{2}$ formed by NOX activity is required for leukocyte recruitment to the wound [172,178]. The role of $\mathrm{H}_{2} \mathrm{O}_{2}$ is not restricted to wounding and healing but extends to other steps of regeneration. When a body part is removed, induction of the regenerative programme correlates with a sustained production of $\mathrm{H}_{2} \mathrm{O}_{2}$ for several hours (Figure 3B) [166]. It has been demonstrated in different model organisms that after amputation, $\mathrm{H}_{2} \mathrm{O}_{2}$ signalling not only modulates the regeneration process but is indispensable for launching it (Table 2). Planarian and Hydra regenerate not only body parts but also their body axis [160,179]. In these animals, ROS are detected at the level of the amputation plane shortly after amputation, and reduction of $\mathrm{H}_{2} \mathrm{O}_{2}$ levels impairs regeneration [164,180] (Figure 3B). In Drosophila, regeneration can be observed in imaginal discs during larval development and adult gut regeneration [181-183]. In both systems, regeneration is redox-dependent [153,181,182,184-187]. In the Xenopus tadpole tail regeneration model, amputation-induced $\mathrm{H}_{2} \mathrm{O}_{2}$ production is necessary to activate Wnt/ $\beta$-catenin, Fgf signalling and acetylation of lysine 9 of histone 3 (H3K9ac) $[165,188]$ (Figure 3B). In the newt, ROS production is also necessary for neural stem cell proliferation, neurogenesis, and regeneration of dopamine neurons [189]. Moreover, recent data demonstrate that $\mathrm{H}_{2} \mathrm{O}_{2}$ activates voltage-gated $\mathrm{Na}^{+}$channels, linking redox signalling to bioelectric signalling during regeneration [190]. During gecko tail regeneration, $\mathrm{H}_{2} \mathrm{O}_{2}$ is produced by skeletal muscles and is also required for successful tail regeneration. In this case, $\mathrm{H}_{2} \mathrm{O}_{2}$ levels control autophagy in the skeletal muscles and consequently the length of the regenerated tail [191]. In adult zebrafish heart, caudal fin and superficial epithelial cells regeneration models, perturbation of ROS levels through the inhibition of NOX or overexpression of catalase impairs regeneration (Figure 3B) [166,167,192,193]. Different targets were identified at the cellular (neural cells), functional (apoptosis), and molecular levels (MAP kinases and Sonic Hedgehog). In mammals, regeneration at adulthood is very limited [194]. The comparison of regeneration of large circular defects through the ear pinna between regenerative mammals (Acomys cahirinus) and non-regenerative mammals (Mus musculus) revealed a strong correlation between $\mathrm{H}_{2} \mathrm{O}_{2}$ levels after injury and regenerative capacities (Figure 3B) [168]. In rats, it was further demonstrated that $\mathrm{H}_{2} \mathrm{O}_{2}$ 
participates in liver regeneration after partial hepatectomy. In this case, sustained and elevated $\mathrm{H}_{2} \mathrm{O}_{2}$ levels activate MAP kinase signalling that triggers the shift from quiescence to proliferation [195]. Recently, it has been demonstrated that $\mathrm{H}_{2} \mathrm{O}_{2}$ produced shortly after inguinal fat pad damage is responsible for its regeneration in MRL mice (Figure 3B). In the non-regenerative C57BL/ 6 strain, artificial enhancement of $\mathrm{H}_{2} \mathrm{O}_{2}$ leads to regeneration [169].

A

Amputation Injury

\begin{tabular}{|ccc|}
\hline Module 1: & Module 2: & Module 3: \\
Injury immediate & Regeneration & Re-development \\
response & induction & \\
\hline
\end{tabular}

B

Amputation
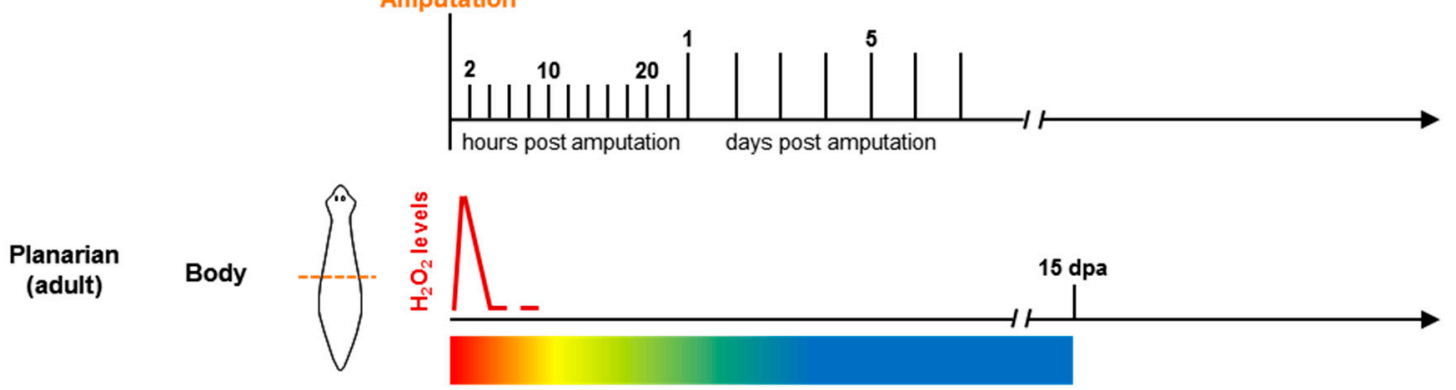

Xenopus (tadpole)

Tail
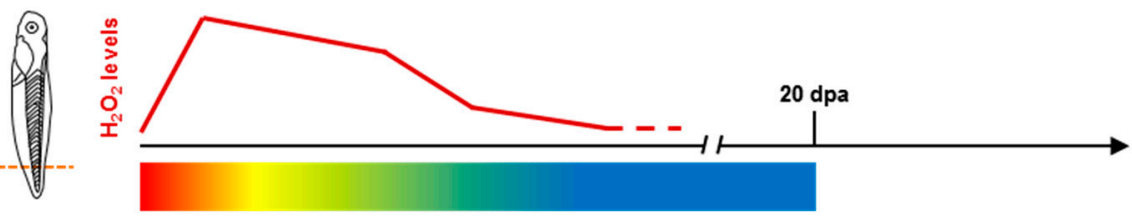

Fin
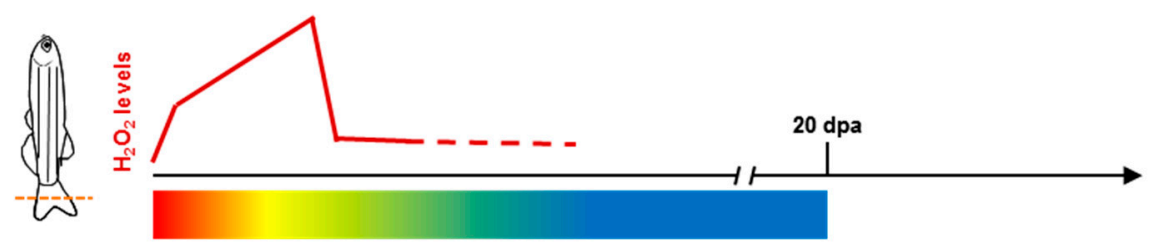

Zebrafish

(adult)
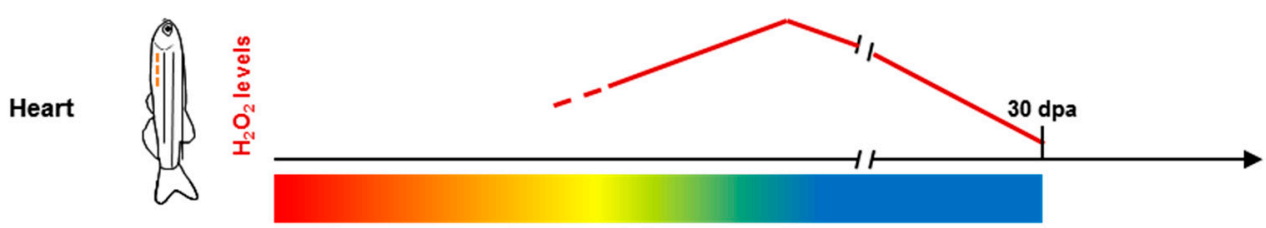

Mice or
Spiny
Mice $\quad$ Ea
(adult)
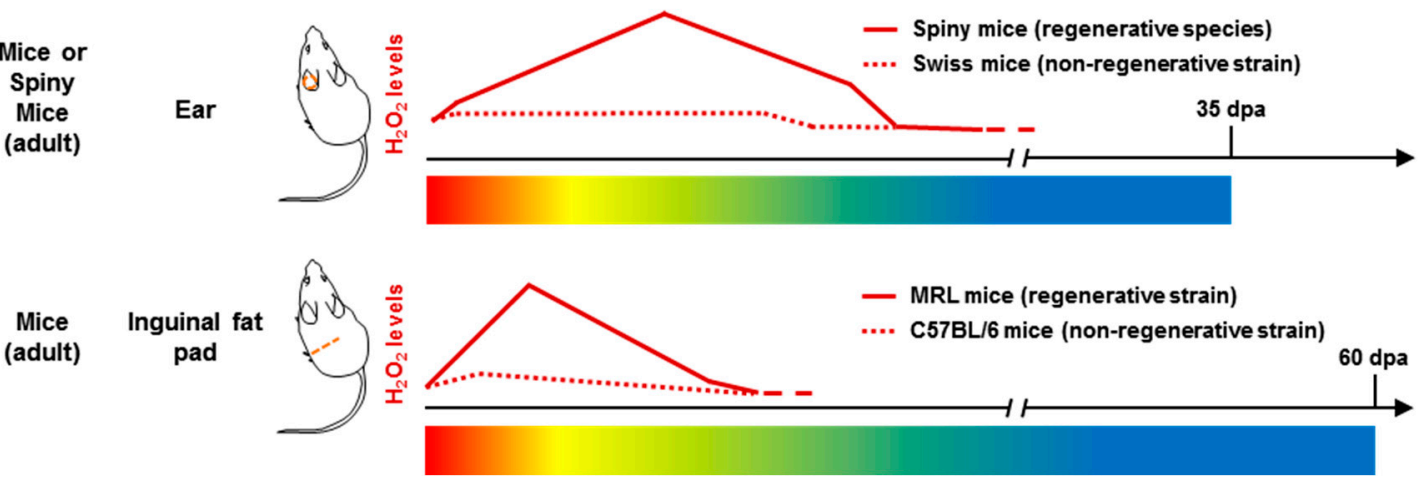

Figure 3. $\mathrm{H}_{2} \mathrm{O}_{2}$ detection during metazoan regeneration. (A): regeneration is divided in three modules. (B): $\mathrm{H}_{2} \mathrm{O}_{2}$ levels during regeneration in different models and organs. dpa: days post amputation. Adapted from [164-170]. 
Table 2. Redox regulation of regeneration among Phyla. APO. apocynin; DHE: dihydroethidium; dpa: days post-amputation; hpa: hours post amputation; n.s.: no significant.

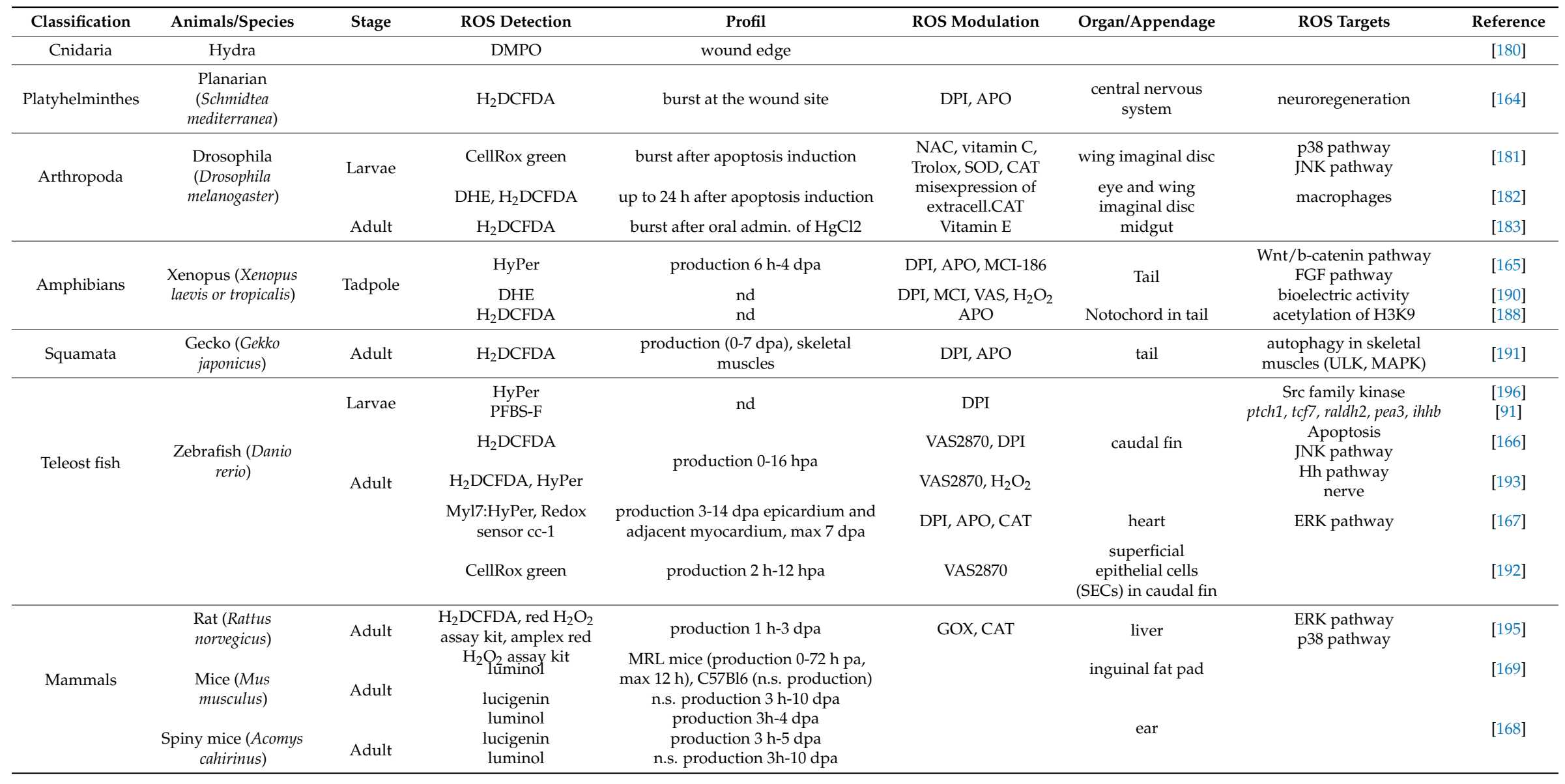




\section{Conclusions: Towards the Redox Code}

Redox signalling interacts directly or indirectly with most of the signalling pathways that control embryonic development. However, we are only starting to perceive the tip of the iceberg [197]. A comprehensive understanding of developmental redox biology will benefit from a better characterization of thiol targets. For this purpose, the optimization of redox proteomics and the in silico identification of reactive thiols susceptible to redox regulation based on 3D rather than 2D models are two promising strategies [198]. One can note that, unlike other posttranslational modifications (i.e., phosphorylation or ubiquitination), which behave as binary switches, thiol modifications are diverse, including the formation of sulfonic acids $(-\mathrm{S}-\mathrm{OH})$, S-nitro groups (S-NO) and disulfides bridges [199]. Each of these modifications could confer a specific status to the targeted protein, thus extending the spectrum of regulation provided by redox signalling [200]. Finally, because the different members of the redox machinery are interconnected, the modification of a specific thiol likely depends on the equilibrium of the entire redox machine. Modelling the entire process by integrating dynamic and quantitative information of the different redox machinery members would greatly help to decipher the physiological role of redox signalling.

Author Contributions: Writing-Review \& Editing, C.R., M.V., A.J. and S.V.

Funding: This work has received support under the programme «Investissements d'Avenir » launched by the French Government and implemented by the ANR with the references: ANR-10-LABX-54 MEMO LIFE, ANR-11-IDEX-0001-02 PSL* Research University.

Acknowledgments: The authors thanks Eva-Maria Hanschmann, Carsten Berndt, Vsevolod Belousov and Helmut Sies for helpful discussions; France Maloumian for drawings; and Carole Gauron for providing zebrafish HyPer Images.

Conflicts of Interest: The authors declare no conflict of interest.

\section{References}

1. Manda-Handzlik, A.; Demkow, U. Neutrophils: The Role of Oxidative and Nitrosative Stress in Health and Disease. Adv. Exp. Med. Biol. 2015, 857, 51-60. [PubMed]

2. Liou, G.Y.; Storz, P. Reactive oxygen species in cancer. Free Radic. Res 2010, 44, 479-496. [CrossRef] [PubMed]

3. Li, J.; Li, W.; Jiang, Z.G.; Ghanbari, H.A. Oxidative stress and neurodegenerative disorders. Int. J. Mol. Sci. 2013, 14, 24438-24475. [CrossRef] [PubMed]

4. Chaturvedi, R.K.; Flint Beal, M. Mitochondrial diseases of the brain. Free Radic. Biol. Med. 2013, 63, 1-29. [CrossRef] [PubMed]

5. Suzuki, Y.J.; Forman, H.J.; Sevanian, A. Oxidants as stimulators of signal transduction. Free Radic. Biol. Med. 1997, 22, 269-285. [CrossRef]

6. D'Autreaux, B.; Toledano, M.B. ROS as signalling molecules: Mechanisms that generate specificity in ROS homeostasis. Nat. Rev. Mol. Cell Biol. 2007, 8, 813-824. [CrossRef] [PubMed]

7. Forman, H.J.; Maiorino, M.; Ursini, F. Signaling functions of reactive oxygen species. Biochemistry 2010, 49, 835-842. [CrossRef] [PubMed]

8. Forman, H.J.; Ursini, F.; Maiorino, M. An overview of mechanisms of redox signaling. J. Mol. Cell Cardiol. 2014, 73, 2-9. [CrossRef] [PubMed]

9. Covarrubias, L.; Hernandez-Garcia, D.; Schnabel, D.; Salas-Vidal, E.; Castro-Obregon, S. Function of reactive oxygen species during animal development: Passive or active? Dev. Biol. 2008, 320, 1-11. [CrossRef] [PubMed]

10. Hernandez-Garcia, D.; Wood, C.D.; Castro-Obregon, S.; Covarrubias, L. Reactive oxygen species: A radical role in development? Free Radic. Biol. Med. 2010, 49, 130-143. [CrossRef] [PubMed]

11. Sies, H. Hydrogen peroxide as a central redox signaling molecule in physiological oxidative stress: Oxidative eustress. Redox Biol. 2017, 11, 613-619. [CrossRef] [PubMed]

12. Nikolaidis, M.G.; Margaritelis, N.V. Same Redox Evidence But Different Physiological "Stories": The Rashomon Effect in Biology. Bioessays 2018, 40, e1800041. [CrossRef] [PubMed] 
13. Di Meo, S.; Reed, T.T.; Venditti, P.; Victor, V.M. Role of ROS and RNS Sources in Physiological and Pathological Conditions. Oxid Med. Cell Longev. 2016, 2016, 1245049. [CrossRef] [PubMed]

14. Tyurina, Y.Y.; Shrivastava, I.; Tyurin, V.A.; Mao, G.; Dar, H.H.; Watkins, S.; Epperly, M.; Bahar, I.; Shvedova, A.A.; Pitt, B.; et al. Only a Life Lived for Others Is Worth Living: Redox Signaling by Oxygenated Phospholipids in Cell Fate Decisions. Antioxid. Redox Signal. 2018, 29, 1333-1358. [CrossRef] [PubMed]

15. Paulsen, C.E.; Carroll, K.S. Orchestrating redox signaling networks through regulatory cysteine switches. ACS Chem. Biol. 2010, 5, 47-62. [CrossRef] [PubMed]

16. Marinho, H.S.; Real, C.; Cyrne, L.; Soares, H.; Antunes, F. Hydrogen peroxide sensing, signaling and regulation of transcription factors. Redox Biol. 2014, 2, 535-562. [CrossRef] [PubMed]

17. Stone, J.R.; Yang, S. Hydrogen peroxide: A signaling messenger. Antioxid. Redox Signal. 2006, 8, $243-270$. [CrossRef] [PubMed]

18. Holmstrom, K.M.; Finkel, T. Cellular mechanisms and physiological consequences of redox-dependent signalling. Nat. Rev. Mol. Cell Biol. 2014, 15, 411-421. [CrossRef] [PubMed]

19. Bedard, K.; Krause, K.H. The NOX family of ROS-generating NADPH oxidases: Physiology and pathophysiology. Physiol. Rev. 2007, 87, 245-313. [CrossRef] [PubMed]

20. Brandes, R.P.; Weissmann, N.; Schroder, K. Nox family NADPH oxidases: Molecular mechanisms of activation. Free Radic. Biol. Med. 2014, 76, 208-226. [CrossRef] [PubMed]

21. Miller, E.W.; Dickinson, B.C.; Chang, C.J. Aquaporin-3 mediates hydrogen peroxide uptake to regulate downstream intracellular signaling. Proc. Natl. Acad. Sci. USA 2010, 107, 15681-15686. [CrossRef] [PubMed]

22. Bienert, G.P.; Chaumont, F. Aquaporin-facilitated transmembrane diffusion of hydrogen peroxide. Biochim. Biophys. Acta 2014, 1840, 1596-1604. [CrossRef] [PubMed]

23. Bertolotti, M.; Farinelli, G.; Galli, M.; Aiuti, A.; Sitia, R. AQP8 transports NOX2-generated $\mathrm{H}_{2} \mathrm{O}_{2}$ across the plasma membrane to promote signaling in B cells. J. Leukoc. Biol. 2016, 100, 1071-1079. [CrossRef] [PubMed]

24. Hara-Chikuma, M.; Watanabe, S.; Satooka, H. Involvement of aquaporin-3 in epidermal growth factor receptor signaling via hydrogen peroxide transport in cancer cells. Biochem. Biophys. Res. Commun. 2016, 471, 603-609. [CrossRef] [PubMed]

25. Bechtel, W.; Bauer, G. Catalase protects tumor cells from apoptosis induction by intercellular ROS signaling. Anticancer Res. 2009, 29, 4541-4557. [PubMed]

26. Heinzelmann, S.; Bauer, G. Multiple protective functions of catalase against intercellular apoptosis-inducing ROS signaling of human tumor cells. Biol. Chem. 2010, 391, 675-693. [CrossRef] [PubMed]

27. Bohm, B.; Heinzelmann, S.; Motz, M.; Bauer, G. Extracellular localization of catalase is associated with the transformed state of malignant cells. Biol. Chem. 2015, 396, 1339-1356. [CrossRef] [PubMed]

28. Moran, E.C.; Kamiguti, A.S.; Cawley, J.C.; Pettitt, A.R. Cytoprotective antioxidant activity of serum albumin and autocrine catalase in chronic lymphocytic leukaemia. Br. J. Haematol. 2002, 116, 316-328. [CrossRef] [PubMed]

29. Poole, L.B. The basics of thiols and cysteines in redox biology and chemistry. Free Radic. Biol. Med. 2015, 80, 148-157. [CrossRef] [PubMed]

30. Delaunay, A.; Isnard, A.D.; Toledano, M.B. $\mathrm{H}_{2} \mathrm{O}_{2}$ sensing through oxidation of the Yap1 transcription factor. EMBO J. 2000, 19, 5157-5166. [CrossRef] [PubMed]

31. Delaunay, A.; Pflieger, D.; Barrault, M.B.; Vinh, J.; Toledano, M.B. A thiol peroxidase is an $\mathrm{H}_{2} \mathrm{O}_{2}$ receptor and redox-transducer in gene activation. Cell 2002, 111, 471-481. [CrossRef]

32. Veal, E.A.; Ross, S.J.; Malakasi, P.; Peacock, E.; Morgan, B.A. Ybp1 is required for the hydrogen peroxide-induced oxidation of the Yap1 transcription factor. J. Biol. Chem. 2003, 278, 30896-30904. [CrossRef] [PubMed]

33. Toledano, M.B.; Delaunay, A.; Monceau, L.; Tacnet, F. Microbial $\mathrm{H}_{2} \mathrm{O}_{2}$ sensors as archetypical redox signaling modules. Trends Biochem. Sci 2004, 29, 351-357. [CrossRef] [PubMed]

34. Gutscher, M.; Sobotta, M.C.; Wabnitz, G.H.; Ballikaya, S.; Meyer, A.J.; Samstag, Y.; Dick, T.P. Proximity-based protein thiol oxidation by $\mathrm{H}_{2} \mathrm{O}_{2}$-scavenging peroxidases. J. Biol. Chem. 2009, 284, 31532-31540. [CrossRef] [PubMed]

35. Calvo, I.A.; Boronat, S.; Domenech, A.; Garcia-Santamarina, S.; Ayte, J.; Hidalgo, E. Dissection of a redox relay: $\mathrm{H}_{2} \mathrm{O}_{2}$-dependent activation of the transcription factor Pap1 through the peroxidatic Tpx1-thioredoxin cycle. Cell Rep. 2013, 5, 1413-1424. [CrossRef] [PubMed] 
36. Sobotta, M.C.; Liou, W.; Stocker, S.; Talwar, D.; Oehler, M.; Ruppert, T.; Scharf, A.N.; Dick, T.P. Peroxiredoxin-2 and STAT3 form a redox relay for $\mathrm{H}_{2} \mathrm{O}_{2}$ signaling. Nat. Chem. Biol. 2015, 11, 64-70. [CrossRef] [PubMed]

37. Veal, E.A.; Day, A.M.; Morgan, B.A. Hydrogen peroxide sensing and signaling. Mol. Cell 2007, 26, 1-14. [CrossRef] [PubMed]

38. Perkins, A.; Nelson, K.J.; Parsonage, D.; Poole, L.B.; Karplus, P.A. Peroxiredoxins: Guardians against oxidative stress and modulators of peroxide signaling. Trends Biochem. Sci. 2015, 40, 435-445. [CrossRef] [PubMed]

39. Netto, L.E.; Antunes, F. The Roles of Peroxiredoxin and Thioredoxin in Hydrogen Peroxide Sensing and in Signal Transduction. Mol. Cells 2016, 39, 65-71. [PubMed]

40. Stocker, S.; Van Laer, K.; Mijuskovic, A.; Dick, T.P. The Conundrum of Hydrogen Peroxide Signaling and the Emerging Role of Peroxiredoxins as Redox Relay Hubs. Antioxid. Redox Signal. 2018, 28, 558-573. [CrossRef] [PubMed]

41. Young, D.; Pedre, B.; Ezerina, D.; De Smet, B.; Lewandowska, A.; Tossounian, M.A.; Bodra, N.; Huang, J.; Astolfi Rosado, L.; Van Breusegem, F.; et al. Protein Promiscuity in $\mathrm{H}_{2} \mathrm{O}_{2}$ Signaling. Antioxid. Redox Signal. 2018. [CrossRef] [PubMed]

42. Hanschmann, E.M.; Godoy, J.R.; Berndt, C.; Hudemann, C.; Lillig, C.H. Thioredoxins, glutaredoxins, and peroxiredoxins-molecular mechanisms and health significance: From cofactors to antioxidants to redox signaling. Antioxid. Redox Signal. 2013, 19, 1539-1605. [CrossRef] [PubMed]

43. Espinosa-Diez, C.; Miguel, V.; Mennerich, D.; Kietzmann, T.; Sanchez-Perez, P.; Cadenas, S.; Lamas, S. Antioxidant responses and cellular adjustments to oxidative stress. Redox Biol. 2015, 6, 183-197. [CrossRef] [PubMed]

44. Reczek, C.R.; Chandel, N.S. ROS-dependdent signal transduction. Curr. Opin. Cell Boil. 2015, 33, 8-13. [CrossRef] [PubMed]

45. Sies, H.; Berndt, C.; Jones, D.P. Oxidative Stress. Ann. Rev Biochem. 2017, 86, 715-748. [CrossRef] [PubMed]

46. Veal, E.A.; Underwood, Z.E.; Tomalin, L.E.; Morgan, B.A.; Pillay, C.S. Hyperoxidation of Peroxiredoxins: Gain or Loss of Function? Antioxid. Redox Signal. 2018, 28, 574-590. [CrossRef] [PubMed]

47. Veal, E.A.; Findlay, V.J.; Day, A.M.; Bozonet, S.M.; Evans, J.M.; Quinn, J.; Morgan, B.A. A 2-Cys peroxiredoxin regulates peroxide-induced oxidation and activation of a stress-activated MAP kinase. Mol. Cell 2004, 15, 129-139. [CrossRef] [PubMed]

48. Tachibana, T.; Okazaki, S.; Murayama, A.; Naganuma, A.; Nomoto, A.; Kuge, S. A major peroxiredoxin-induced activation of Yap1 transcription factor is mediated by reduction-sensitive disulfide bonds and reveals a low level of transcriptional activation. J. Biol. Chem. 2009, 284, 4464-4472. [CrossRef] [PubMed]

49. Iwai, K.; Naganuma, A.; Kuge, S. Peroxiredoxin Ahp1 acts as a receptor for alkylhydroperoxides to induce disulfide bond formation in the Cad1 transcription factor. J. Biol. Chem. 2010, 285, 10597-10604. [CrossRef] [PubMed]

50. Fomenko, D.E.; Koc, A.; Agisheva, N.; Jacobsen, M.; Kaya, A.; Malinouski, M.; Rutherford, J.C.; Siu, K.L.; Jin, D.Y.; Winge, D.R.; et al. Thiol peroxidases mediate specific genome-wide regulation of gene expression in response to hydrogen peroxide. Proc. Natl. Acad. Sci. USA 2011, 108, 2729-2734. [CrossRef] [PubMed]

51. Jarvis, R.M.; Hughes, S.M.; Ledgerwood, E.C. Peroxiredoxin 1 functions as a signal peroxidase to receive, transduce, and transmit peroxide signals in mammalian cells. Free Radic. Biol. Med. 2012, 53, 1522-1530. [CrossRef] [PubMed]

52. Stocker, S.; Maurer, M.; Ruppert, T.; Dick, T.P. A role for 2-Cys peroxiredoxins in facilitating cytosolic protein thiol oxidation. Nat. Chem. Biol. 2018, 14, 148-155. [CrossRef] [PubMed]

53. Gomes, A.; Fernandes, E.; Lima, J.L. Fluorescence probes used for detection of reactive oxygen species. J. Biochem. Biophys. Methods 2005, 65, 45-80. [CrossRef] [PubMed]

54. Rhee, S.G.; Chang, T.S.; Jeong, W.; Kang, D. Methods for detection and measurement of hydrogen peroxide inside and outside of cells. Mol. Cells 2010, 29, 539-549. [CrossRef] [PubMed]

55. Kalyanaraman, B.; Darley-Usmar, V.; Davies, K.J.; Dennery, P.A.; Forman, H.J.; Grisham, M.B.; Mann, G.E.; Moore, K.; Roberts, L.J., 2nd; Ischiropoulos, H. Measuring reactive oxygen and nitrogen species with fluorescent probes: Challenges and limitations. Free Radic. Biol. Med. 2012, 52, 1-6. [CrossRef] [PubMed] 
56. Belousov, V.V.; Fradkov, A.F.; Lukyanov, K.A.; Staroverov, D.B.; Shakhbazov, K.S.; Terskikh, A.V.; Lukyanov, S. Genetically encoded fluorescent indicator for intracellular hydrogen peroxide. Nat. Methods 2006, 3, 281-286. [CrossRef] [PubMed]

57. Poburko, D.; Santo-Domingo, J.; Demaurex, N. Dynamic regulation of the mitochondrial proton gradient during cytosolic calcium elevations. J. Biol. Chem. 2011, 286, 11672-11684. [CrossRef] [PubMed]

58. Bilan, D.S.; Belousov, V.V. HyPer Family Probes: State of the Art. Antioxid. Redox Signal. 2016, $24,731-751$. [CrossRef] [PubMed]

59. Han, Y.; Ishibashi, S.; Iglesias-Gonzalez, J.; Chen, Y.; Love, N.R.; Amaya, E. Ca ${ }^{2+}$-Induced Mitochondrial ROS Regulate the Early Embryonic Cell Cycle. Cell Rep. 2018, 22, 218-231. [CrossRef] [PubMed]

60. Knoefler, D.; Thamsen, M.; Koniczek, M.; Niemuth, N.J.; Diederich, A.K.; Jakob, U. Quantitative in vivo redox sensors uncover oxidative stress as an early event in life. Mol. Cell 2012, 47, 767-776. [CrossRef] [PubMed]

61. Gauron, C.; Meda, F.; Dupont, E.; Albadri, S.; Quenech’Du, N.; Ipendey, E.; Volovitch, M.; Del Bene, F.; Joliot, A.; Rampon, C.; et al. Hydrogen peroxide $\left(\mathrm{H}_{2} \mathrm{O}_{2}\right)$ controls axon pathfinding during zebrafish development. Dev. Biol. 2016, 414, 133-141. [CrossRef] [PubMed]

62. Back, P.; De Vos, W.H.; Depuydt, G.G.; Matthijssens, F.; Vanfleteren, J.R.; Braeckman, B.P. Exploring real-time in vivo redox biology of developing and aging Caenorhabditis elegans. Free Radic. Biol. Med. 2012, 52, 850-859. [CrossRef] [PubMed]

63. Morgan, B.; Van Laer, K.; Owusu, T.N.; Ezerina, D.; Pastor-Flores, D.; Amponsah, P.S.; Tursch, A.; Dick, T.P. Real-time monitoring of basal $\mathrm{H}_{2} \mathrm{O}_{2}$ levels with peroxiredoxin-based probes. Nat. Chem. Biol. 2016, 12, 437-443. [CrossRef] [PubMed]

64. Albrecht, S.C.; Barata, A.G.; Grosshans, J.; Teleman, A.A.; Dick, T.P. In vivo mapping of hydrogen peroxide and oxidized glutathione reveals chemical and regional specificity of redox homeostasis. Cell Metab. 2011, 14, 819-829. [CrossRef] [PubMed]

65. Braeckman, B.P.; Smolders, A.; Back, P.; De Henau, S. In Vivo Detection of Reactive Oxygen Species and Redox Status in Caenorhabditis elegans. Antioxid. Redox Signal. 2016, 25, 577-592. [CrossRef] [PubMed]

66. Fujikawa, Y.; Roma, L.P.; Sobotta, M.C.; Rose, A.J.; Diaz, M.B.; Locatelli, G.; Breckwoldt, M.O.; Misgeld, T.; Kerschensteiner, M.; Herzig, S.; et al. Mouse redox histology using genetically encoded probes. Sci. Signal 2016, 9, rs1. [CrossRef] [PubMed]

67. Panieri, E.; Millia, C.; Santoro, M.M. Real-time quantification of subcellular $\mathrm{H}_{2} \mathrm{O}_{2}$ and glutathione redox potential in living cardiovascular tissues. Free Radic. Biol. Med. 2017, 109, 189-200. [CrossRef] [PubMed]

68. Gutscher, M.; Pauleau, A.L.; Marty, L.; Brach, T.; Wabnitz, G.H.; Samstag, Y.; Meyer, A.J.; Dick, T.P. Real-time imaging of the intracellular glutathione redox potential. Nat. Methods 2008, 5, 553-559. [CrossRef] [PubMed]

69. Tao, R.; Zhao, Y.; Chu, H.; Wang, A.; Zhu, J.; Chen, X.; Zou, Y.; Shi, M.; Liu, R.; Su, N.; et al. Genetically encoded fluorescent sensors reveal dynamic regulation of NADPH metabolism. Nat. Methods 2017, 14, 720-728. [CrossRef] [PubMed]

70. Ufer, C.; Wang, C.C.; Borchert, A.; Heydeck, D.; Kuhn, H. Redox control in mammalian embryo development. Antioxid. Redox Signal. 2010, 13, 833-875. [CrossRef] [PubMed]

71. Forman, H.J. Redox signaling: An evolution from free radicals to aging. Free Radic. Biol. Med. 2016, 97, 398-407. [CrossRef] [PubMed]

72. Ren, X.; Zou, L.; Zhang, X.; Branco, V.; Wang, J.; Carvalho, C.; Holmgren, A.; Lu, J. Redox Signaling Mediated by Thioredoxin and Glutathione Systems in the Central Nervous System. Antioxid. Redox Signal. 2017, 27, 989-1010. [CrossRef] [PubMed]

73. Wilson, C.; Munoz-Palma, E.; Gonzalez-Billault, C. From birth to death: A role for reactive oxygen species in neuronal development. Semin. Cell Dev. Biol. 2018, 80, 43-49. [CrossRef] [PubMed]

74. Olguin-Albuerne, M.; Moran, J. Redox Signaling Mechanisms in Nervous System Development. Antioxid. Redox Signal. 2018, 28, 1603-1625. [CrossRef] [PubMed]

75. Morishita, H.; Cabungcal, J.H.; Chen, Y.; Do, K.Q.; Hensch, T.K. Prolonged Period of Cortical Plasticity upon Redox Dysregulation in Fast-Spiking Interneurons. Biol. Psychiatry 2015, 78, 396-402. [CrossRef] [PubMed]

76. Do, K.Q.; Cabungcal, J.H.; Frank, A.; Steullet, P.; Cuenod, M. Redox dysregulation, neurodevelopment, and schizophrenia. Curr. Opin. Neurobiol. 2009, 19, 220-230. [CrossRef] [PubMed] 
77. Le Belle, J.E.; Sperry, J.; Ngo, A.; Ghochani, Y.; Laks, D.R.; Lopez-Aranda, M.; Silva, A.J.; Kornblum, H.I. Maternal inflammation contributes to brain overgrowth and autism-associated behaviors through altered redox signaling in stem and progenitor cells. Stem. Cell Rep. 2014, 3, 725-734. [CrossRef] [PubMed]

78. Katsuyama, M. NOX/NADPH oxidase, the superoxide-generating enzyme: Its transcriptional regulation and physiological roles. J. Pharmacol. Sci. 2010, 114, 134-146. [CrossRef] [PubMed]

79. Weaver, C.J.; Leung, Y.F.; Suter, D.M. Expression dynamics of NADPH oxidases during early zebrafish development. J. Comp. Neurol. 2016, 524, 2130-2141. [CrossRef] [PubMed]

80. Milenkovic, M.; De Deken, X.; Jin, L.; De Felice, M.; Di Lauro, R.; Dumont, J.E.; Corvilain, B.; Miot, F. Duox expression and related $\mathrm{H}_{2} \mathrm{O}_{2}$ measurement in mouse thyroid: Onset in embryonic development and regulation by TSH in adult. J. Endocrinol. 2007, 192, 615-626. [CrossRef] [PubMed]

81. Kim, K.S.; Choi, H.W.; Yoon, H.E.; Kim, I.Y. Reactive oxygen species generated by NADPH oxidase 2 and 4 are required for chondrogenic differentiation. J. Biol. Chem. 2010, 285, 40294-40302. [CrossRef] [PubMed]

82. Li, J.; Stouffs, M.; Serrander, L.; Banfi, B.; Bettiol, E.; Charnay, Y.; Steger, K.; Krause, K.H.; Jaconi, M.E. The NADPH oxidase NOX4 drives cardiac differentiation: Role in regulating cardiac transcription factors and MAP kinase activation. Mol. Biol. Cell 2006, 17, 3978-3988. [CrossRef] [PubMed]

83. Buggisch, M.; Ateghang, B.; Ruhe, C.; Strobel, C.; Lange, S.; Wartenberg, M.; Sauer, H. Stimulation of ES-cell-derived cardiomyogenesis and neonatal cardiac cell proliferation by reactive oxygen species and NADPH oxidase. J. Cell Sci. 2007, 120, 885-894. [CrossRef] [PubMed]

84. Ren, F.; Wang, K.; Zhang, T.; Jiang, J.; Nice, E.C.; Huang, C. New insights into redox regulation of stem cell self-renewal and differentiation. Biochim. Biophys. Acta 2015, 1850, 1518-1526. [CrossRef] [PubMed]

85. Skonieczna, M.; Hejmo, T.; Poterala-Hejmo, A.; Cieslar-Pobuda, A.; Buldak, R.J. NADPH Oxidases: Insights into Selected Functions and Mechanisms of Action in Cancer and Stem Cells. Oxid. Med. Cell Longev. 2017, 2017, 9420539. [CrossRef] [PubMed]

86. Thisse, B.; Thisse, C. Fast Release Clones: A High Throughput Expression Analysis. ZFIN Direct Data Submiss. 2004, in press.

87. Brautigam, L.; Schutte, L.D.; Godoy, J.R.; Prozorovski, T.; Gellert, M.; Hauptmann, G.; Holmgren, A.; Lillig, C.H.; Berndt, C. Vertebrate-specific glutaredoxin is essential for brain development. Proc. Natl. Acad. Sci. USA 2011, 108, 20532-20537. [CrossRef] [PubMed]

88. Haunhorst, P.; Hanschmann, E.M.; Brautigam, L.; Stehling, O.; Hoffmann, B.; Muhlenhoff, U.; Lill, R.; Berndt, C.; Lillig, C.H. Crucial function of vertebrate glutaredoxin 3 (PICOT) in iron homeostasis and hemoglobin maturation. Mol. Biol. Cell 2013, 24, 1895-1903. [CrossRef] [PubMed]

89. Wingert, R.A.; Galloway, J.L.; Barut, B.; Foott, H.; Fraenkel, P.; Axe, J.L.; Weber, G.J.; Dooley, K.; Davidson, A.J.; Schmid, B.; et al. Deficiency of glutaredoxin 5 reveals Fe-S clusters are required for vertebrate haem synthesis. Nature 2005, 436, 1035-1039. [CrossRef] [PubMed]

90. Thisse, B.; Pflumio, S.; Fürthauer, M.; Loppin, B.; Heyer, V. Expression of the zebrafish genome during embryogenesis (NIH R01 RR15402). ZFIN Direct Data Submiss. 2001, in press.

91. Yang, L.; Kemadjou, J.R.; Zinsmeister, C.; Bauer, M.; Legradi, J.; Muller, F.; Pankratz, M.; Jakel, J.; Strahle, U. Transcriptional profiling reveals barcode-like toxicogenomic responses in the zebrafish embryo. Genome Biol. 2007, 8, R227. [CrossRef] [PubMed]

92. Seiler, C.; Davuluri, G.; Abrams, J.; Byfield, F.J.; Janmey, P.A.; Pack, M. Smooth muscle tension induces invasive remodeling of the zebrafish intestine. PLoS Biol. 2012, 10, e1001386. [CrossRef] [PubMed]

93. Mendieta-Serrano, M.A.; Schnabel, D.; Lomeli, H.; Salas-Vidal, E. Spatial and temporal expression of zebrafish glutathione peroxidase $4 \mathrm{a}$ and $\mathrm{b}$ genes during early embryo development. Gene Expr. Patterns 2015, 19, 98-107. [CrossRef] [PubMed]

94. Rong, X.; Zhou, Y.; Liu, Y.; Zhao, B.; Wang, B.; Wang, C.; Gong, X.; Tang, P.; Lu, L.; Li, Y.; et al. Glutathione peroxidase 4 inhibits $\mathrm{Wnt} /$ beta-catenin signaling and regulates dorsal organizer formation in zebrafish embryos. Development 2017, 144, 1687-1697. [CrossRef] [PubMed]

95. Flores, M.V.; Crawford, K.C.; Pullin, L.M.; Hall, C.J.; Crosier, K.E.; Crosier, P.S. Dual oxidase in the intestinal epithelium of zebrafish larvae has anti-bacterial properties. Biochem. Biophys. Res. Commun. 2010, 400, 164-168. [CrossRef] [PubMed]

96. Opitz, R.; Maquet, E.; Zoenen, M.; Dadhich, R.; Costagliola, S. TSH receptor function is required for normal thyroid differentiation in zebrafish. Mol. Endocrinol. 2011, 25, 1579-1599. [CrossRef] [PubMed] 
97. Huang, P.C.; Chiu, C.C.; Chang, H.W.; Wang, Y.S.; Syue, H.H.; Song, Y.C.; Weng, Z.H.; Tai, M.H.; Wu, C.Y. Prdx1-encoded peroxiredoxin is important for vascular development in zebrafish. FEBS Lett. 2017, 591, 889-902. [CrossRef] [PubMed]

98. Nakajima, H.; Nakajima-Takagi, Y.; Tsujita, T.; Akiyama, S.; Wakasa, T.; Mukaigasa, K.; Kaneko, H.; Tamaru, Y.; Yamamoto, M.; Kobayashi, M. Tissue-restricted expression of Nrf2 and its target genes in zebrafish with gene-specific variations in the induction profiles. PLoS ONE 2011, 6, e26884. [CrossRef] [PubMed]

99. Hegde, A.; Qiu, N.C.; Qiu, X.; Ho, S.H.; Tay, K.Q.; George, J.; Ng, F.S.; Govindarajan, K.R.; Gong, Z.; Mathavan, S.; et al. Genomewide expression analysis in zebrafish mind bomb alleles with pancreas defects of different severity identifies putative Notch responsive genes. PLoS ONE 2008, 3, e1479. [CrossRef] [PubMed]

100. Bazzini, A.A.; Lee, M.T.; Giraldez, A.J. Ribosome profiling shows that miR-430 reduces translation before causing mRNA decay in zebrafish. Science 2012, 336, 233-237. [CrossRef] [PubMed]

101. Peterman, E.M.; Sullivan, C.; Goody, M.F.; Rodriguez-Nunez, I.; Yoder, J.A.; Kim, C.H. Neutralization of mitochondrial superoxide by superoxide dismutase 2 promotes bacterial clearance and regulates phagocyte numbers in zebrafish. Infect. Immun. 2015, 83, 430-440. [CrossRef] [PubMed]

102. Priyadarshini, M.; Tuimala, J.; Chen, Y.C.; Panula, P. A zebrafish model of PINK1 deficiency reveals key pathway dysfunction including HIF signaling. Neurobiol. Dis. 2013, 54, 127-138. [CrossRef] [PubMed]

103. Weaver, C.J.; Terzi, A.; Roeder, H.; Gurol, T.; Deng, Q.; Leung, Y.F.; Suter, D.M. nox2/cybb Deficiency Affects Zebrafish Retinotectal Connectivity. J. Neurosci. 2018, 38, 5854-5871. [CrossRef] [PubMed]

104. Chopra, K.; Ishibashi, S.; Amaya, E. Zebrafish duox mutations provide a model for human congenital hypothyroidism. bioRxiv 2018. [CrossRef]

105. Al-Sabbagh, M.; Fusi, L.; Higham, J.; Lee, Y.; Lei, K.; Hanyaloglu, A.C.; Lam, E.W.; Christian, M.; Brosens, J.J. NADPH oxidase-derived reactive oxygen species mediate decidualization of human endometrial stromal cells in response to cyclic AMP signaling. Endocrinology 2011, 152, 730-740. [CrossRef] [PubMed]

106. Wilson, C.; Nunez, M.T.; Gonzalez-Billault, C. Contribution of NADPH oxidase to the establishment of hippocampal neuronal polarity in culture. J. Cell Sci. 2015, 128, 2989-2995. [CrossRef] [PubMed]

107. Wilson, C.; Munoz-Palma, E.; Henriquez, D.R.; Palmisano, I.; Nunez, M.T.; Di Giovanni, S.; Gonzalez-Billault, C. A Feed-Forward Mechanism Involving the NOX Complex and RyR-Mediated Ca2+ Release During Axonal Specification. J. Neurosci. 2016, 36, 11107-11119. [CrossRef] [PubMed]

108. Olguin-Albuerne, M.; Moran, J. ROS produced by NOX2 control in vitro development of cerebellar granule neurons development. ASN Neuro 2015, 7. [CrossRef] [PubMed]

109. Munnamalai, V.; Suter, D.M. Reactive oxygen species regulate F-actin dynamics in neuronal growth cones and neurite outgrowth. J. Neurochem. 2009, 108, 644-661. [CrossRef] [PubMed]

110. Zhang, X.F.; Forscher, P. Rac1 modulates stimulus-evoked $\mathrm{Ca}^{2+}$ release in neuronal growth cones via parallel effects on microtubule/endoplasmic reticulum dynamics and reactive oxygen species production. Mol. Biol. Cell 2009, 20, 3700-3712. [CrossRef] [PubMed]

111. Munnamalai, V.; Weaver, C.J.; Weisheit, C.E.; Venkatraman, P.; Agim, Z.S.; Quinn, M.T.; Suter, D.M. Bidirectional interactions between NOX2-type NADPH oxidase and the F-actin cytoskeleton in neuronal growth cones. J. Neurochem. 2014, 130, 526-540. [CrossRef] [PubMed]

112. Boudreau, H.E.; Casterline, B.W.; Rada, B.; Korzeniowska, A.; Leto, T.L. Nox4 involvement in TGF-beta and SMAD3-driven induction of the epithelial-to-mesenchymal transition and migration of breast epithelial cells. Free Radic. Biol. Med. 2012, 53, 1489-1499. [CrossRef] [PubMed]

113. Wu, Y.H.; Lee, Y.H.; Shih, H.Y.; Chen, S.H.; Cheng, Y.C.; Tsun-Yee Chiu, D. Glucose-6-phosphate dehydrogenase is indispensable in embryonic development by modulation of epithelial-mesenchymal transition via the NOX/Smad3/miR-200b axis. Cell Death Dis. 2018, 9, 10. [CrossRef] [PubMed]

114. el-Hage, S.; Singh, S.M. Temporal expression of genes encoding free radical-metabolizing enzymes is associated with higher mRNA levels during in utero development in mice. Dev. Genet. 1990, 11, 149-159. [CrossRef] [PubMed]

115. Radyuk, S.N.; Klichko, V.I.; Orr, W.C. Catalase expression in Drosophila melanogaster is responsive to ecdysone and exhibits both transcriptional and post-transcriptional regulation. Arch. Insect Biochem. Physiol. 2000, 45, 79-93. [CrossRef]

116. Hansen, J.M.; Harris, C. Glutathione during embryonic development. Biochim. Biophys. Acta 2015, 1850, 1527-1542. [CrossRef] [PubMed] 
117. Shi, Z.Z.; Osei-Frimpong, J.; Kala, G.; Kala, S.V.; Barrios, R.J.; Habib, G.M.; Lukin, D.J.; Danney, C.M.; Matzuk, M.M.; Lieberman, M.W. Glutathione synthesis is essential for mouse development but not for cell growth in culture. Proc. Natl. Acad. Sci. USA 2000, 97, 5101-5106. [CrossRef] [PubMed]

118. Winkler, A.; Njalsson, R.; Carlsson, K.; Elgadi, A.; Rozell, B.; Abraham, L.; Ercal, N.; Shi, Z.Z.; Lieberman, M.W.; Larsson, A.; et al. Glutathione is essential for early embryogenesis-Analysis of a glutathione synthetase knockout mouse. Biochem. Biophys Res. Commun. 2011, 412, 121-126. [CrossRef] [PubMed]

119. Timme-Laragy, A.R.; Goldstone, J.V.; Imhoff, B.R.; Stegeman, J.J.; Hahn, M.E.; Hansen, J.M. Glutathione redox dynamics and expression of glutathione-related genes in the developing embryo. Free Radic. Biol. Med. 2013, 65, 89-101. [CrossRef] [PubMed]

120. Jurado, J.; Prieto-Alamo, M.J.; Madrid-Risquez, J.; Pueyo, C. Absolute gene expression patterns of thioredoxin and glutaredoxin redox systems in mouse. J. Biol. Chem. 2003, 278, 45546-45554. [CrossRef] [PubMed]

121. Karunakaran, S.; Saeed, U.; Ramakrishnan, S.; Koumar, R.C.; Ravindranath, V. Constitutive expression and functional characterization of mitochondrial glutaredoxin (Grx2) in mouse and human brain. Brain Res. 2007, 1185, 8-17. [CrossRef] [PubMed]

122. Lonn, M.E.; Hudemann, C.; Berndt, C.; Cherkasov, V.; Capani, F.; Holmgren, A.; Lillig, C.H. Expression pattern of human glutaredoxin 2 isoforms: Identification and characterization of two testis/cancer cell-specific isoforms. Antioxid. Redox Signal. 2008, 10, 547-557. [CrossRef] [PubMed]

123. Hudemann, C.; Lonn, M.E.; Godoy, J.R.; Zahedi Avval, F.; Capani, F.; Holmgren, A.; Lillig, C.H. Identification, expression pattern, and characterization of mouse glutaredoxin 2 isoforms. Antioxid. Redox Signal. 2009, 11, 1-14. [CrossRef] [PubMed]

124. Choi, C.H.; Kim, B.J.; Jeong, S.Y.; Lee, C.H.; Kim, J.S.; Park, S.J.; Yim, H.S.; Kang, S.O. Reduced glutathione levels affect the culmination and cell fate decision in Dictyostelium discoideum. Dev. Biol. 2006, 295, 523-533. [CrossRef] [PubMed]

125. Gellert, M.; Venz, S.; Mitlohner, J.; Cott, C.; Hanschmann, E.M.; Lillig, C.H. Identification of a dithiol-disulfide switch in collapsin response mediator protein 2 (CRMP2) that is toggled in a model of neuronal differentiation. J. Biol. Chem. 2013, 288, 35117-35125. [CrossRef] [PubMed]

126. Brautigam, L.; Jensen, L.D.; Poschmann, G.; Nystrom, S.; Bannenberg, S.; Dreij, K.; Lepka, K.; Prozorovski, T.; Montano, S.J.; Aktas, O.; et al. Glutaredoxin regulates vascular development by reversible glutathionylation of sirtuin 1. Proc. Natl. Acad. Sci. USA 2013, 110, 20057-20062. [CrossRef] [PubMed]

127. Berndt, C.; Poschmann, G.; Stuhler, K.; Holmgren, A.; Brautigam, L. Zebrafish heart development is regulated via glutaredoxin 2 dependent migration and survival of neural crest cells. Redox Biol. 2014, 2, 673-678. [CrossRef] [PubMed]

128. Cheng, N.H.; Zhang, W.; Chen, W.Q.; Jin, J.; Cui, X.; Butte, N.F.; Chan, L.; Hirschi, K.D. A mammalian monothiol glutaredoxin, Grx3, is critical for cell cycle progression during embryogenesis. FEBS J. 2011, 278, 2525-2539. [CrossRef] [PubMed]

129. Pham, K.; Dong, J.; Jiang, X.; Qu, Y.; Yu, H.; Yang, Y.; Olea, W.; Marini, J.C.; Chan, L.; Wang, J.; et al. Loss of glutaredoxin 3 impedes mammary lobuloalveolar development during pregnancy and lactation. Am. J. Physiol. Endocrinol. Metab. 2017, 312, E136-E149. [CrossRef] [PubMed]

130. Lillig, C.H.; Berndt, C.; Holmgren, A. Glutaredoxin systems. Biochim. Biophys. Acta 2008, 1780, $1304-1317$. [CrossRef] [PubMed]

131. Fujii, S.; Nanbu, Y.; Konishi, I.; Mori, T.; Masutani, H.; Yodoi, J. Immunohistochemical localization of adult T-cell leukaemia-derived factor, a human thioredoxin homologue, in human fetal tissues. Virchows Arch. A Pathol. Anat. Histopathol. 1991, 419, 317-326. [CrossRef] [PubMed]

132. Matsui, M.; Oshima, M.; Oshima, H.; Takaku, K.; Maruyama, T.; Yodoi, J.; Taketo, M.M. Early embryonic lethality caused by targeted disruption of the mouse thioredoxin gene. Dev. Biol. 1996, 178, 179-185. [CrossRef] [PubMed]

133. Nonn, L.; Williams, R.R.; Erickson, R.P.; Powis, G. The absence of mitochondrial thioredoxin 2 causes massive apoptosis, exencephaly, and early embryonic lethality in homozygous mice. Mol. Cell. Biol. 2003, 23, 916-922. [CrossRef] [PubMed]

134. Zhang, J.; Cui, X.; Wang, L.; Liu, F.; Jiang, T.; Li, C.; Li, D.; Huang, M.; Liao, S.; Wang, J.; et al. The mitochondrial thioredoxin is required for liver development in zebrafish. Curr. Mol. Med. 2014, 14, 772-782. [CrossRef] [PubMed] 
135. Pirson, M.; Debrulle, S.; Clippe, A.; Clotman, F.; Knoops, B. Thioredoxin-2 Modulates Neuronal Programmed Cell Death in the Embryonic Chick Spinal Cord in Basal and Target-Deprived Conditions. PLoS ONE 2015, 10, e0142280. [CrossRef] [PubMed]

136. Jakupoglu, C.; Przemeck, G.K.; Schneider, M.; Moreno, S.G.; Mayr, N.; Hatzopoulos, A.K.; de Angelis, M.H.; Wurst, W.; Bornkamm, G.W.; Brielmeier, M.; et al. Cytoplasmic thioredoxin reductase is essential for embryogenesis but dispensable for cardiac development. Mol. Cell Biol. 2005, 25, 1980-1988. [CrossRef] [PubMed]

137. Conrad, M.; Jakupoglu, C.; Moreno, S.G.; Lippl, S.; Banjac, A.; Schneider, M.; Beck, H.; Hatzopoulos, A.K.; Just, U.; Sinowatz, F.; et al. Essential role for mitochondrial thioredoxin reductase in hematopoiesis, heart development, and heart function. Mol. Cell Biol. 2004, 24, 9414-9423. [CrossRef] [PubMed]

138. Lu, J.; Holmgren, A. The thioredoxin antioxidant system. Free Radic. Biol. Med. 2014, 66, 75-87. [CrossRef] [PubMed]

139. Hurd, T.R.; DeGennaro, M.; Lehmann, R. Redox regulation of cell migration and adhesion. Trends Cell Biol. 2012, 22, 107-115. [CrossRef] [PubMed]

140. DeGennaro, M.; Hurd, T.R.; Siekhaus, D.E.; Biteau, B.; Jasper, H.; Lehmann, R. Peroxiredoxin stabilization of DE-cadherin promotes primordial germ cell adhesion. Dev. Cell 2011, 20, 233-243. [CrossRef] [PubMed]

141. Shafer, M.E.; Willson, J.A.; Damjanovski, S. Expression analysis of the peroxiredoxin gene family during early development in Xenopus laevis. Gene Expr. Patterns 2011, 11, 511-516. [CrossRef] [PubMed]

142. Shan, S.W.; Tang, M.K.; Cai, D.Q.; Chui, Y.L.; Chow, P.H.; Grotewold, L.; Lee, K.K. Comparative proteomic analysis identifies protein disulfide isomerase and peroxiredoxin 1 as new players involved in embryonic interdigital cell death. Dev. Dyn. 2005, 233, 266-281. [CrossRef] [PubMed]

143. Yan, Y.; Sabharwal, P.; Rao, M.; Sockanathan, S. The antioxidant enzyme Prdx1 controls neuronal differentiation by thiol-redox-dependent activation of GDE2. Cell 2009, 138, 1209-1221. [CrossRef] [PubMed]

144. Yan, Y.; Wladyka, C.; Fujii, J.; Sockanathan, S. $\mathrm{Prdx} 4$ is a compartment-specific $\mathrm{H}_{2} \mathrm{O}_{2}$ sensor that regulates neurogenesis by controlling surface expression of GDE2. Nat. Commun. 2015, 6, 7006. [CrossRef] [PubMed]

145. Morimoto, H.; Iwata, K.; Ogonuki, N.; Inoue, K.; Atsuo, O.; Kanatsu-Shinohara, M.; Morimoto, T.; Yabe-Nishimura, C.; Shinohara, T. ROS are required for mouse spermatogonial stem cell self-renewal. Cell Stem Cell 2013, 12, 774-786. [CrossRef] [PubMed]

146. Conrad, M.; Ingold, I.; Buday, K.; Kobayashi, S.; Angeli, J.P. ROS, thiols and thiol-regulating systems in male gametogenesis. Biochim. Biophys. Acta 2015, 1850, 1566-1574. [CrossRef] [PubMed]

147. Noblanc, A.; Kocer, A.; Chabory, E.; Vernet, P.; Saez, F.; Cadet, R.; Conrad, M.; Drevet, J.R. Glutathione peroxidases at work on epididymal spermatozoa: An example of the dual effect of reactive oxygen species on mammalian male fertilizing ability. J. Androl. 2011, 32, 641-650. [CrossRef] [PubMed]

148. Bigarella, C.L.; Liang, R.; Ghaffari, S. Stem cells and the impact of ROS signaling. Development 2014, 141, 4206-4218. [CrossRef] [PubMed]

149. Tatapudy, S.; Aloisio, F.; Barber, D.; Nystul, T. Cell fate decisions: Emerging roles for metabolic signals and cell morphology. EMBO Rep. 2017, 18, 2105-2118. [CrossRef] [PubMed]

150. Owusu-Ansah, E.; Banerjee, U. Reactive oxygen species prime Drosophila haematopoietic progenitors for differentiation. Nature 2009, 461, 537-541. [CrossRef] [PubMed]

151. Su, B.; Mitra, S.; Gregg, H.; Flavahan, S.; Chotani, M.A.; Clark, K.R.; Goldschmidt-Clermont, P.J.; Flavahan, N.A. Redox regulation of vascular smooth muscle cell differentiation. Circ. Res. 2001, 89, 39-46. [CrossRef] [PubMed]

152. Jang, Y.Y.; Sharkis, S.J. A low level of reactive oxygen species selects for primitive hematopoietic stem cells that may reside in the low-oxygenic niche. Blood 2007, 110, 3056-3063. [CrossRef] [PubMed]

153. Hochmuth, C.E.; Biteau, B.; Bohmann, D.; Jasper, H. Redox regulation by Keap1 and Nrf2 controls intestinal stem cell proliferation in Drosophila. Cell Stem. Cell 2011, 8, 188-199. [CrossRef] [PubMed]

154. Le Belle, J.E.; Orozco, N.M.; Paucar, A.A.; Saxe, J.P.; Mottahedeh, J.; Pyle, A.D.; Wu, H.; Kornblum, H.I. Proliferative neural stem cells have high endogenous ROS levels that regulate self-renewal and neurogenesis in a PI3K/Akt-dependant manner. Cell Stem. Cell 2011, 8, 59-71. [CrossRef] [PubMed]

155. Dickinson, B.C.; Peltier, J.; Stone, D.; Schaffer, D.V.; Chang, C.J. Nox2 redox signaling maintains essential cell populations in the brain. Nat. Chem. Biol. 2011, 7, 106-112. [CrossRef] [PubMed]

156. Zhou, G.; Meng, S.; Li, Y.; Ghebre, Y.T.; Cooke, J.P. Optimal ROS Signaling Is Critical for Nuclear Reprogramming. Cell Rep. 2016, 15, 919-925. [CrossRef] [PubMed] 
157. Kang, X.; Wei, X.; Wang, X.; Jiang, L.; Niu, C.; Zhang, J.; Chen, S.; Meng, D. Nox2 contributes to the arterial endothelial specification of mouse induced pluripotent stem cells by upregulating Notch signaling. Sci. Rep. 2016, 6, 33737. [CrossRef] [PubMed]

158. Sanchez Alvarado, A. Regeneration in the metazoans: Why does it happen? Bioessays 2000, 22, 578-590. [CrossRef]

159. Brockes, J.P.; Kumar, A. Comparative aspects of animal regeneration. Ann. Rev. Cell Dev. Biol. 2008, 24, 525-549. [CrossRef] [PubMed]

160. Galliot, B.; Ghila, L. Cell plasticity in homeostasis and regeneration. Mol. Reprod. Dev. 2010, 77, 837-855. [CrossRef] [PubMed]

161. Poss, K.D. Advances in understanding tissue regenerative capacity and mechanisms in animals. Nat. Rev. Genet. 2010, 11, 710-722. [CrossRef] [PubMed]

162. Sandoval-Guzman, T.; Wang, H.; Khattak, S.; Schuez, M.; Roensch, K.; Nacu, E.; Tazaki, A.; Joven, A.; Tanaka, E.M.; Simon, A. Fundamental differences in dedifferentiation and stem cell recruitment during skeletal muscle regeneration in two salamander species. Cell Stem Cell 2014, 14, 174-187. [CrossRef] [PubMed]

163. Meda, F.; Rampon, C.; Dupont, E.; Gauron, C.; Mourton, A.; Queguiner, I.; Thauvin, M.; Volovitch, M.; Joliot, A.; Vriz, S. Nerves, $\mathrm{H}_{2} \mathrm{O}_{2}$ and Shh: Three players in the game of regeneration. Semin. Cell Dev. Biol. 2018, 80, 65-73. [CrossRef] [PubMed]

164. Pirotte, N.; Stevens, A.S.; Fraguas, S.; Plusquin, M.; Van Roten, A.; Van Belleghem, F.; Paesen, R.; Ameloot, M.; Cebria, F.; Artois, T.; et al. Reactive Oxygen Species in Planarian Regeneration: An Upstream Necessity for Correct Patterning and Brain Formation. Oxid Med. Cell Longev. 2015, 2015, 392476. [CrossRef] [PubMed]

165. Love, N.R.; Chen, Y.; Ishibashi, S.; Kritsiligkou, P.; Lea, R.; Koh, Y.; Gallop, J.L.; Dorey, K.; Amaya, E. Amputation-induced reactive oxygen species are required for successful Xenopus tadpole tail regeneration. Nat. Cell Biol. 2013, 15, 222-228. [CrossRef] [PubMed]

166. Gauron, C.; Rampon, C.; Bouzaffour, M.; Ipendey, E.; Teillon, J.; Volovitch, M.; Vriz, S. Sustained production of ROS triggers compensatory proliferation and is required for regeneration to proceed. Sci. Rep. 2013, 3, 2084. [CrossRef] [PubMed]

167. Han, P.; Zhou, X.H.; Chang, N.; Xiao, C.L.; Yan, S.; Ren, H.; Yang, X.Z.; Zhang, M.L.; Wu, Q.; Tang, B.; et al. Hydrogen peroxide primes heart regeneration with a derepression mechanism. Cell Res 2014, 29, 1091-1107. [CrossRef] [PubMed]

168. Simkin, J.; Gawriluk, T.R.; Gensel, J.C.; Seifert, A.W. Macrophages are necessary for epimorphic regeneration in African spiny mice. eLife 2017, 6, e24623. [CrossRef] [PubMed]

169. Labit, E.; Rabiller, L.; Rampon, C.; Guissard, C.; Andre, M.; Barreau, C.; Cousin, B.; Carriere, A.; Eddine, M.A.; Pipy, B.; et al. Opioids prevent regeneration in adult mammals through inhibition of ROS production. Sci. Rep. 2018, 8, 12170. [CrossRef] [PubMed]

170. Chen, Y.; Love, N.R.; Amaya, E. Tadpole tail regeneration in Xenopus. Biochem. Soc. Trans. 2014, 42, 617-623. [CrossRef] [PubMed]

171. Roy, S.; Khanna, S.; Nallu, K.; Hunt, T.K.; Sen, C.K. Dermal wound healing is subject to redox control. Mol. Ther. 2006, 13, 211-220. [CrossRef] [PubMed]

172. Niethammer, P.; Grabher, C.; Look, A.T.; Mitchison, T.J. A tissue-scale gradient of hydrogen peroxide mediates rapid wound detection in zebrafish. Nature 2009, 459, 996-999. [CrossRef] [PubMed]

173. Moreira, S.; Stramer, B.; Evans, I.; Wood, W.; Martin, P. Prioritization of competing damage and developmental signals by migrating macrophages in the Drosophila embryo. Curr. Biol. 2010, 20, 464-470. [CrossRef] [PubMed]

174. Xu, S.; Chisholm, A.D. C. elegans epidermal wounding induces a mitochondrial ROS burst that promotes wound repair. Dev. Cell. 2014, 31, 48-60. [CrossRef] [PubMed]

175. Leon, J.; Rojo, E.; Sanchez-Serrano, J.J. Wound signalling in plants. J. Exp. Bot. 2001, 52, 1-9. [CrossRef] [PubMed]

176. Orozco-Cardenas, M.L.; Narvaez-Vasquez, J.; Ryan, C.A. Hydrogen peroxide acts as a second messenger for the induction of defense genes in tomato plants in response to wounding, systemin, and methyl jasmonate. Plant Cell 2001, 13, 179-191. [CrossRef] [PubMed]

177. Suzuki, N.; Mittler, R. Reactive oxygen species-dependent wound responses in animals and plants. Free Radic. Biol. Med. 2012, 53, 2269-2276. [CrossRef] [PubMed] 
178. Yoo, S.K.; Starnes, T.W.; Deng, Q.; Huttenlocher, A. Lyn is a redox sensor that mediates leukocyte wound attraction in vivo. Nature 2011, 480, 109-112. [CrossRef] [PubMed]

179. Sanchez Alvarado, A.; Newmark, P.A. The use of planarians to dissect the molecular basis of metazoan regeneration. Wound Rep. Regen. 1998, 6, 413-420.

180. Vriz, S.; Reiter, S.; Galliot, B. Cell death: A program to regenerate. Curr. Top. Dev. Biol. 2014, 108, $121-151$. [PubMed]

181. Santabarbara-Ruiz, P.; Lopez-Santillan, M.; Martinez-Rodriguez, I.; Binagui-Casas, A.; Perez, L.; Milan, M.; Corominas, M.; Serras, F. ROS-Induced JNK and p38 Signaling Is Required for Unpaired Cytokine Activation during Drosophila Regeneration. PLoS Genet. 2015, 11, e1005595. [CrossRef] [PubMed]

182. Fogarty, C.E.; Diwanji, N.; Lindblad, J.L.; Tare, M.; Amcheslavsky, A.; Makhijani, K.; Bruckner, K.; Fan, Y.; Bergmann, A. Extracellular Reactive Oxygen Species Drive Apoptosis-Induced Proliferation via Drosophila Macrophages. Curr. Biol. 2016, 26, 575-584. [CrossRef] [PubMed]

183. Chen, Z.; Wu, X.; Luo, H.; Zhao, L.; Ji, X.; Qiao, X.; Jin, Y.; Liu, W. Acute exposure of mercury chloride stimulates the tissue regeneration program and reactive oxygen species production in the Drosophila midgut. Environ. Toxicol. Pharmacol. 2016, 41, 32-38. [CrossRef] [PubMed]

184. Khan, S.J.; Abidi, S.N.F.; Skinner, A.; Tian, Y.; Smith-Bolton, R.K. The Drosophila Duox maturation factor is a key component of a positive feedback loop that sustains regeneration signaling. PLoS Genet. 2017, 13, e1006937. [CrossRef] [PubMed]

185. Brock, A.R.; Seto, M.; Smith-Bolton, R.K. Cap-n-Collar Promotes Tissue Regeneration by Regulating ROS and JNK Signaling in the Drosophila melanogaster Wing Imaginal Disc. Genetics 2017, 206, 1505-1520. [CrossRef] [PubMed]

186. Diwanji, N.; Bergmann, A. The beneficial role of extracellular reactive oxygen species in apoptosis-induced compensatory proliferation. Fly (Austin) 2017, 11, 46-52. [CrossRef] [PubMed]

187. Amcheslavsky, A.; Wang, S.; Fogarty, C.E.; Lindblad, J.L.; Fan, Y.; Bergmann, A. Plasma Membrane Localization of Apoptotic Caspases for Non-apoptotic Functions. Dev. Cell. 2018, 45, 450-464.e3. [CrossRef] [PubMed]

188. Suzuki, M.; Takagi, C.; Miura, S.; Sakane, Y.; Suzuki, M.; Sakuma, T.; Sakamoto, N.; Endo, T.; Kamei, Y.; Sato, Y.; et al. In vivo tracking of histone $\mathrm{H} 3$ lysine 9 acetylation in Xenopus laevis during tail regeneration. Genes Cells 2016, 21, 358-369. [CrossRef] [PubMed]

189. Hameed, L.S.; Berg, D.A.; Belnoue, L.; Jensen, L.D.; Cao, Y.; Simon, A. Environmental changes in oxygen tension reveal ROS-dependent neurogenesis and regeneration in the adult newt brain. eLife 2015, 4, e08422. [CrossRef] [PubMed]

190. Ferreira, F.; Luxardi, G.; Reid, B.; Zhao, M. Early bioelectric activities mediate redox-modulated regeneration. Development 2016, 143, 4582-4594. [CrossRef] [PubMed]

191. Zhang, Q.; Wang, Y.; Man, L.; Zhu, Z.; Bai, X.; Wei, S.; Liu, Y.; Liu, M.; Wang, X.; Gu, X.; et al. Reactive oxygen species generated from skeletal muscles are required for gecko tail regeneration. Sci. Rep. 2016, 6, 20752. [CrossRef] [PubMed]

192. Chen, C.H.; Puliafito, A.; Cox, B.D.; Primo, L.; Fang, Y.; Di Talia, S.; Poss, K.D. Multicolor Cell Barcoding Technology for Long-Term Surveillance of Epithelial Regeneration in Zebrafish. Dev. Cell. 2016, 36, 668-680. [CrossRef] [PubMed]

193. Meda, F.; Gauron, C.; Rampon, C.; Teillon, J.; Volovitch, M.; Vriz, S. Nerves Control Redox Levels in Mature Tissues Through Schwann Cells and Hedgehog Signaling. Antioxid. Redox Signal. 2016, 24, $299-311$. [CrossRef] [PubMed]

194. Bely, A.E.; Nyberg, K.G. Evolution of animal regeneration: Re-emergence of a field. Trends Ecol. Evol. 2010, 25, 161-170. [CrossRef] [PubMed]

195. Bai, H.; Zhang, W.; Qin, X.J.; Zhang, T.; Wu, H.; Liu, J.Z.; Hai, C.X. Hydrogen peroxide modulates the proliferation/quiescence switch in the liver during embryonic development and posthepatectomy regeneration. Antioxid. Redox Signal. 2015, 22, 921-937. [CrossRef] [PubMed]

196. Yoo, S.K.; Freisinger, C.M.; Lebert, D.C.; Huttenlocher, A. Early redox, Src family kinase, and calcium signaling integrate wound responses and tissue regeneration in zebrafish. J. Cell. Biol. 2012, 199, 225-234. [CrossRef] [PubMed]

197. Vriz, S. Redox signalling in development and regeneration. Semin. Cell. Dev. Biol. 2018, 80, 1-2. [CrossRef] [PubMed] 
198. Go, Y.M.; Chandler, J.D.; Jones, D.P. The cysteine proteome. Free Radic. Biol. Med. 2015, 84, $227-245$. [CrossRef] [PubMed]

199. Herrmann, J.M.; Dick, T.P. Redox Biology on the rise. Biol. Chem. 2012, 393, 999-1004. [CrossRef] [PubMed]

200. Jones, D.P.; Sies, H. The Redox Code. Antioxid. Redox Signal. 2015, 23, 734-746. [CrossRef] [PubMed]

(C) 2018 by the authors. Licensee MDPI, Basel, Switzerland. This article is an open access article distributed under the terms and conditions of the Creative Commons Attribution (CC BY) license (http:/ / creativecommons.org/licenses/by/4.0/). 